\title{
Bacteria-mediated reduction of As(V)-doped lepidocrocite in a flooded soil sample
}

\author{
Aline Dia ${ }^{1}$, Béatrice Lauga ${ }^{2}$, Mélanie Davranche ${ }^{1}$, Anne Fahy $^{2}$, \\ Robert Duran ${ }^{2}$, Bernd Nowack ${ }^{3}$, Patrice Petitjean ${ }^{1}$, Odile Henin ${ }^{1}$, Sébastien \\ Martin ${ }^{1}$, Rémi Marsac ${ }^{1}$ and Gérard Gruau ${ }^{1}$ \\ ${ }^{1}$ CNRS - UMR 6118 Géosciences Rennes - Bât. 14B - Campus Beaulieu - Université Rennes 1, 35042 \\ Rennes Cedex, France \\ ${ }^{2}$ Équipe Environnement et Microbiologie, UMR CNRS 5254, IPREM, EEM, Université de Pau et des \\ Pays de l'Adour, IBEAS, BP 1155, 64013 Pau Cedex, France ${ }^{3}$ Empa-Swiss Federal Laboratories \\ for Materials Testing and Research Technology \& Society Laboratory Environmental Risk \\ Assessment and Management Group Lerchenfeldstrasse, \\ 5 CH-9014 St. Gallen, Switzerland
}

Corresponding author: A. Dia - e-mail: dia@univ-rennes1.fr - Phone: 33223235650 - Fax: 33223236280

This document is the accepted manuscript version of the following article: Dia, A., Lauga, B., Davranche, M., Fahy, A., Duran, R., Nowack, B., Petitjean, P., Henin, o., Martin, S., Marsac, R., \& Gruau, G. (2015). Bacteria-mediated reduction of As(V)-doped 1epidocrocite in a flooded soil sample. Chemical Geology, 406, 34-44.

https://doi.org/10.1016/j.chemgeo.2015.04.008 


\section{Highlights:}

- At the beginning of the experiment, the slides were colonized by fermentative bacteria and Geobacter Fe-reducing bacteria.

- This colonization was accompanied by a release of Fe(II) and As(III) in solution.

- The formation of 3-dimensionally shaped biodissolution of lepidocrocite on the slides was evidenced.

- T-RFLP profiling and cloning/sequencing revealed a successional process through time.

- Members of the community harboring genes involved in the detoxification processes may transform $\mathrm{As}(\mathrm{V})$ into $\mathrm{As}(\mathrm{III})$.

Keywords: Bioreduction. Iron oxide/Bacteria interactions. Arsenic. Wetland soil. 
ABSTRACT. Understanding the processes involved in the control of arsenic (As) dynamics within soils has become a challenging issue for soil and water quality preservation. Interactions between mineralogical phases, organic ligands and bacterial communities closely linked to the chemical conditions of the medium - were thus investigated through a geochemical and microbiological experimental study involving the reduction of As(V)-doped lepidocrocite within the soil. Reducing conditions were established as soon as the experiment started, followed by a release of dissolved organic carbon corresponding to a release of acetate. Scanning Electron Microscopy observations pointed out a large bacterial colonization occurring on the lepidocrocite leading to a 3-dimensionally shaped biodissolution of lepidocrocite. The taxonomic diversity evolved throughout the experiment, and thus it demonstrated the evolution of the metabolic activities of the bacteria. At the beginning, lepidocrocite was mainly colonized by bacteria belonging to the Geobacter genus (Deltaproteobacteria) (26\%) and Bacillus and Oxalophagus fermentative related genera (Firmicutes) (72\%). After two weeks, Geobacter spp. and Firmicutes represented 54\% and $30 \%$ of the bacterial community, respectively. Although still dominated by Geobacter spp. $(34 \%)$ at the end of the experiment, the bacterial diversity had increased. After 3 and 8 weeks of incubation, the presence of the $\operatorname{ars} B$ and $A C R 3(1)$ genes, encoding transporters involved in As detoxification processes, indicated that this community harbored As-resistant or Astransforming genera able to contribute to the transformation of $\mathrm{As}(\mathrm{V})$ into $\mathrm{As}(\mathrm{III})$.

\section{INTRODUCTION}

Iron (III) oxides are ubiquitous mineral constituents of soils, sediments, aquifers and geological materials. Their respective stability, specific surface area, porosity, dissolution rate as well as transformation kinetics are controlled by their mineral structure (Cornell and Schwertmann, 2003). The precipitation and dissolution of Fe oxides are dependent on the $\mathrm{pH}$, 
redox state and occurrence of organic ligands (McBride, 1994), which are themselves controlled by microbial activities. The key role of microorganisms in the biogeochemical cycling of Fe has been well assessed (Lovley and Phillips, 1986; Lovley, 1991; Lovley et al., 1991; Wahid and Kamalam, 1993; Roden and Zachara, 1996). Fe-reducing bacteria, which are ubiquitous in waterlogged soils, couple the oxidation of organic matter with the reduction of various Fe(III) oxyhydroxides for their metabolism (Francis and Dodge, 1990; Lovley and Phillips, 1986; Chuan et al., 1996; Charlatchka and Cambier, 2000; Green et al., 2003; Quantin et al., 2001; 2002; Grybos et al., 2007). This functional group is phylogenetically diverse. It comprises bacteria that conserve energy to support growth from $\mathrm{Fe}(\mathrm{III})$ reduction and those that do not possess this potential (Lovley, 2006).

A direct consequence of $\mathrm{Fe}(\mathrm{III})$ reduction is the release of the associated trace metals into the soil solution (e.g. Schwertmann and Taylor, 1989; Lovley and Coates, 1997; Davranche and Bollinger, 2000; 2001; Quantin et al., 2001; Zachara et al., 2001; Van Geen et al., 2004; Burnol et al., 2007; Jönsson and Sherman, 2008). Therefore, the biogeochemical cycles and fate of $\mathrm{Fe}$ and the associated trace metals are closely linked (Francis and Dodge, 1990; Lovley, 1991). As a consequence, the sorption and redox chemistry of Fe(III) oxides have been widely studied in near-surface geochemical systems (Charlatchka and Cambier, 2000; Davranche and Bollinger, 2000; Davranche et al., 2003; Bonneville et al., 2004; Grybos et al., 2007). Under oxic conditions, crystallized or amorphous Fe(III) mineral phases are able to incorporate or scavenge toxic trace elements such as $\mathrm{As}, \mathrm{Cr}, \mathrm{Cd}$ or $\mathrm{Pb}$ (Bousserrhine et al., 1999; Morin et al., 1999; Brown and Sturchio, 2002; Morin et al., 2002; Bonneville et al., 2004; Morin and Calas, 2006). Secondary Fe(II)-Fe(III)-containing minerals, such as green rusts and magnetite (Lovley et al., 1987; Ona-Nguema et al., 2002; Zachara et al., 2002; Glasauer et al., 2003; Ona-Nguema et al., 2004; Zegeye et al., 2005), have been shown to scavenge trace elements (e.g., Cooper et al., 2000; Coker et al., 2006; Root et al., 2007; Wang 
et al., 2008; Ona-Nguema et al., 2009). Among the trace metals, arsenic (As) is strongly adsorbed onto Fe-oxides (Manning et al., 1998; Raven et al., 1998; Dixit and Hering, 2003), which are probably the largest carriers of As in aquifers and soils (Morin et al., 2002; Morin and Calas, 2006; Cancès et al., 2005; 2008). Arsenic occurs at concentrations exceeding potable levels in major aquifers in several parts of the world, especially in South Asia (Smedley and Kinniburgh, 2002; Islam et al., 2004; Van Geen et al., 2008). High As concentrations in subsurface waters have been shown to often result from the reductive dissolution of hydrous Fe-oxides and the subsequent release of associated As (Nickson et al., 2000; Bose and Sharma, 2002; Van Geen et al., 2004). When As(V) is released, a subsequent bioreduction to As(III) can be performed by microorganisms via two processes: the first involves dissimilatory arsenate-respiring prokaryotes (DARPs) that will reduce As(V) using organic matter as an electron donor to obtain energy and to support growth, whereas the second is the consequence of detoxification strategies that expel As(III) from the cell after As $(V)$ has entered the microbial cell through phosphate transporters (Lloyd and Oremland, 2006).

In the natural environment, the mineral soil matrix could also strongly influence the mechanism of the reductive dissolution and therefore the nature of the secondary minerals (for example, due to $\mathrm{Fe}(\mathrm{II})$ adsorption or As solubilization). Until recently, it was still a challenge to study the processes involved in bioreduction directly in soils despite a large set of experimental studies (Jorgensen and Willems, 1987; Voeglin et al., 2002; Jenkinson and Franzheimer, 2006). However, Fakih et al. (2008) developed a method inspired from Birkefeld et al. (2005) to monitor the transformation of Fe-oxides directly within soils and to quantify their reductive dissolution. Iron oxides are precipitated onto acrylic slides, which can be directly inserted into the soil. 
Considering the crucial need for addressing interdisciplinary approaches combining geochemistry and microbiology to understand Fe-oxide bioreduction mechanisms, we used the monitoring tool recently developed by Fakih et al. $(2008 ; 2009)$ to investigate the reductive dissolution of $\mathrm{As}(\mathrm{V})$-doped lepidocrocite directly in a soil sample. The aims of this study were: (i) to quantify Fe and As release over time, (ii) to unravel the role of bacteria in Fe-oxide bioreduction, (iii) to describe over time the bacterial consortia involved and their respective functional role with regards to $\mathrm{Fe}$ and As dynamics at the soil/water interface. One of the key questions confronting geochemical and microbiological data is: who is doing what, as well as how and when, with regards to Fe and associated As?

\section{MATERIALS AND METHODS}

All of the chemicals used were of analytical grade. The solutions were prepared with double de-ionized water (Milli-Q system, Millipore). The containers used were (i) soaked in $10 \%$ ultrapure $\mathrm{HNO}_{3}$ for $48 \mathrm{~h}$ at $60^{\circ} \mathrm{C}$ to remove all possible contaminant sources, (ii) soaked in Milli-Q water for $24 \mathrm{~h}$ at $60^{\circ} \mathrm{C}$, and finally (iii) dried at $30^{\circ} \mathrm{C}$.

\subsection{Iron oxide-covered slides}

A technique based on slides coated by Fe-oxyhydroxides (Birkefeld et al., 2005; Fakih et al., 2008) was used. The tool consists of small $(2 \times 2 \times 0.2 \mathrm{~cm})$ striated polymer plates covered by synthetic As(V)-lepidocrocite (As-Lp). The detailed methodology for the production of the slides, their characterization and the method validation are further detailed in Fakih et al. (2008). Lepidocrocite was synthesized in the presence of As(V) according to the protocol given by Schwertmann and Cornell (2000). The average amount of Fe coating the slides was $0.7 \pm 0.2 \mathrm{mg}$ per slide (Fakih et al., 2009). The mass ratio of As and Fe was 0.005 (i.e. $3.5 \mu \mathrm{g}$ of As per slide). Although the question of the form into which As was 
incorporated into the lepidocrocite was not addressed through this study, As was probably mostly sorbed onto lepidocrocite via an inner-sphere complex (Randall et al., 2001; Pedersen et al., 2006; Ona-Nguema et al., 2009). The surface area of the lepidocrocite, measured by a multi-point BET method (using a Micromeritics FlowSorb II 2300 apparatus equipped with a LECO TC-436 analyzer), was determined as $65.1 \mathrm{~m}^{2} \mathrm{~g}^{-1}$. The As(V)-lepidocrocite mineralogy was assessed by XRD analyses performed on a Siemens D500 diffractometer (Figure A.1, supporting information). The BET and XRD analyses were performed at the Chemical Sciences Department at the University of Rennes 1.

\subsection{Soil sampling}

Soil was sampled from the Mercy wetland located in the Naizin-Kervidy/Coët-Dan subcatchment in Brittany, Western France (Curmi et al., 1997). This catchment is particularly well adapted to study the reductive dissolution of Fe because redox cycles involving Fe have been identified in these soils (Dia et al., 2000; Olivié-Lauquet et al., 2001). Wetland soil was sampled in the uppermost organo-mineral horizon (Ah) of a planosol (according to the WRB international classification). The soil was collected in January 2010 at the beginning of the water table rise and the wetland reduction period. The collected soil sample was dried at $30^{\circ} \mathrm{C}$ for $72 \mathrm{~h}$, and then sieved to $2 \mathrm{~mm}$ (AFNOR, 2004). After fusion of the sample with $\mathrm{LiBO}_{2}$ flux and acidic dissolution with $\mathrm{HNO}_{3}$, the major and trace element composition was determined at the CNRS Analytical Research Facility - SARM - (France), by InductivelyCoupled Plasma Optical Emission Spectrometry and Mass Spectrometry (ICP-OES, Thermo Elemental IRIS radial and ICP-MS, Agilent 7700X) for the major and trace elements, respectively (Table 1). The soil organic carbon content was determined using a carbon-sulfur analyzer (Leco SC144 DRPC) (Table 1). The major element concentrations in the soil sample are given in Table 1. The soil sample contained $1.40 \mathrm{wt} . \%$ of Fe, $6.64 \mathrm{wt} . \%$ of organic carbon 
and $7.64 \mu \mathrm{g} \mathrm{g}^{-1}$ of As. Water extraction performed for a soil/water ratio of 20 (in weight) showed that $26 \mathrm{mg} \mathrm{L}^{-1}$ versus $105 \mathrm{mg} \mathrm{L}^{-1}$ of DOC could be solubilized under oxidative conditions at $\mathrm{pH} 3$ and 7, respectively. In a previous study conducted by Davranche et al. (2011), a comparable soil sample recovered within the same uppermost organo-mineral horizon (Ah) was sequentially leached following the modified BCR (European Communities Bureau of Reference) extraction scheme (Mossop and Davidson, 2003). The distribution of Fe showed that $23 \%$ of Fe lies in the reducible fraction (as amorphous Fe(III)-oxyhydroxides), $24 \%$ in the oxidizable fraction (as organic complexes or sulfides) and $52 \%$ in the residual fraction (Fe as well crystallized Fe(III)-oxyhydroxides and/or Fe in clays and/or Fe in relict primary minerals).

\subsection{Experimental set-up}

Columns suited for anaerobic conditions are described in detail in Fakih et al. (2009). Briefly, two reservoirs are connected by a flexible tygon tube with an internal diameter of 0.2 $\mathrm{mm}$. The columns were operated in up-flow mode. The solution percolated gently through the soil sample from the bottom of the column and was returned back to the solution reservoir. The solution $(800 \mathrm{~mL})$ was continuously flushed through the soil column at a flow rate of 20 $\mathrm{mL} \mathrm{h}^{-1}$ using a peristaltic pump (Ismatec Ecoline). The solution circulated in a closed system. Forty grams of a dried and sieved soil sample were placed into a $250 \mathrm{ml}$ polypropylene reservoir. Two horizontal perforated Teflon disks (with a pore size of $69 \mu \mathrm{m}$ ) retained the soil sample particles in the reservoir. The total porosity in the soil columns (i.e., pore water volume) was $56 \%$. Four coated As(V)-Lp slides were inserted in the soil sample. The chemical composition and ionic strength of the percolating solution were chosen to be comparable to that of the pore water in the Mercy wetland just at the beginning of the flooded period $\left(30.71 \mathrm{mg} \mathrm{L}^{-1}\right.$ of $\mathrm{NaCl}, 30.91 \mathrm{mg} \mathrm{L}^{-1}$ of $\mathrm{NaNO}_{3}$ and $10.62 \mathrm{mg} \mathrm{L}^{-1}$ of $\mathrm{Na}_{2} \mathrm{SO}_{4}$ and $\mathrm{pH}$ 
$=5.9$ ). The incubation experiments were performed at a constant temperature of $22 \pm 0.6^{\circ} \mathrm{C}$ in a Jacomex glove box under purified $\mathrm{N}_{2}$ flow $\left(<10 \mathrm{ppm} \mathrm{O}_{2}\right.$ and $\mathrm{H}_{2} \mathrm{O}$ ). As previously evidenced, the coated As(V)-Lp oxide slides did not chemically disturb, or only did so very slightly, the soil system (Fakih et al., 2008). If the whole reducible and oxidizable fractions of the Fe soil content would be solubilized by the reductive dissolution and the concomitant $\mathrm{pH}$ increase processes, the released Fe amount would be $0.26 \mathrm{~g}$. If the As(V)-Lp oxide from the four slides would be totally dissolved, $0.0028 \mathrm{~g}$ of Fe would be released in the solution, i.e. $1.04 \%$ of the potentially solubilizable soil Fe. The slides were removed by sacrificing each column at different time intervals over a two month period $(1,2,3,4,6$ and 8 weeks of incubation). Since the experimental procedure required a very large number of microbiological and geochemical analyses, fully replicated experiments were not conducted. However, each data point corresponds to one sacrificed anaerobic column and the displayed kinetics of the analyzed solute are consistent through time. Each column served as a replicate to the other columns (Parsons et al., 2013). The recovered slides were rinsed with de-oxygenated deionized water under nitrogen atmosphere to remove the soil sample particles. Then, at each sampling time: (i) two slides devoted to the SEM observations were maintained under anaerobic conditions. Incubated slides were dried at the critical point (Fakih et al., 2008). The surfaces of the slides were observed by Scanning Electron Microscopy (SEM) with a JEOL JSM-6301F Field Emission Gun Scanning Electron Microscope operating at $9 \mathrm{kV}$ after being coated with Au-Pd nano-particles by cathodic deposition with a JEOL JFC 1100 sputter. (ii) Two slides devoted to microbiological analyses were collected with sterilized clips, stored in sterile Petri boxes and frozen at $-18^{\circ} \mathrm{C}$ until needed.

\subsection{Soil solution sampling and chemical analyses}

Roughly $5 \mathrm{ml}$ of solution were taken at each sampling point. The samples were filtered with 
$0.2 \mu \mathrm{m}$ cellulose acetate membranes (Millipore) and aliquoted for the analysis of the total metals, $\mathrm{Fe}(\mathrm{II})$, acetate, $\mathrm{SO}_{4}{ }^{2-}$ and $\mathrm{NO}_{3}{ }^{-}$. Solution sampling and filtration were carried out in a Jacomex glove box to prevent $\mathrm{Fe}(\mathrm{II})$ and $\mathrm{As}(\mathrm{III})$ oxidation. The $\mathrm{pH}$ and Eh were measured in $1 \mathrm{~mL}$ of non-filtered solution using an InLab combined $\mathrm{pH}$ and $\mathrm{Pt}$ electrode. The measured Eh data were corrected to be presented relative to the standard hydrogen electrode (SHE) readings. Dissolved Fe(II) concentrations were quantified by the 1.10 phenantroline colorimetric method, AFNOR NF T90-017 (AFNOR, 1997) at $510 \mathrm{~nm}$ using a UV-visible spectrophotometer (UV/VIS Spectrometer (UVIKON XS, Bio-Tek) with a precision of $\pm 5 \%$. $\mathrm{NO}_{3}{ }^{-}, \mathrm{SO}_{4}{ }^{2-}$ and acetate concentrations were analyzed by ion chromatography (Dionex, model $\mathrm{X} 120$ ), with a precision of $\pm 4 \%$. The total concentration of the major and trace elements was analyzed with an Agilent Technologies HP4500 ICP-MS instrument using indium as an internal standard. The international geostandard SLRS-4 was used to check the validity and reproducibility of the results, and the instrumental error on the $\mathrm{Fe}$ analysis was $<5 \%$ (Yéguicheyan et al., 2001; Davranche et al., 2004). Since monomethylarsonic acid (MMA) and dimethylarsinic acid (DMMA) are considered as insignificant in reduced soil solution (Masscheleyn et al., 1991), we focused the investigation on As(III) and As(V). Total As and As(III) were measured by the $\mathrm{pH}$-selective hydride generation/separation technique coupled with atomic absorption spectrometric detection (SOLAAR GF95 graphite furnace) with an accuracy of $\pm 5 \%$ and $\pm 8 \%$, respectively (Michon, 2006). The amount of As(V) was estimated by subtracting As(III) from the total As. Dissolved organic carbon (DOC) and dissolved inorganic carbon (DIC) were measured using a Total Organic Carbon analyzer (Shimadzu TOC-5050A). The accuracy of the DOC and DIC measurements was estimated to be $\pm 3 \%$ (by using a standard solution of potassium hydrogen phthalate) and 4\% (by using a standard solution of sodium carbonate-bicarbonate), respectively. 


\subsection{Speciation modelling}

Modelling calculations were performed with PHREEQC/Model VI (Marsac et al., 2011). This model was used to calculate the speciation (saturation index, redox, mixing, sorption, etc.) in organic rich-solutions. The "minteq.v4" database was completed by both (i) the solubility constants of the reduced solid phases possibly encountered, such as green rusts, hydroxy-green rusts, etc. (Rickard and Luther, 2007), and (ii) Model(VI) specific binding parameters corresponding to the complexation of $\mathrm{Ca}, \mathrm{Mg}, \mathrm{Al}(\mathrm{III}) \mathrm{Fe}(\mathrm{II})$ and $\mathrm{Fe}$ (III) with the organic matter. Specific binding parameters for $\mathrm{Ca}, \mathrm{Mg}$ and $\mathrm{Fe}(\mathrm{II})$ are from Tipping (1998) and those for $\mathrm{Al}(\mathrm{III})$ and $\mathrm{Fe}(\mathrm{III})$ are from Marsac et al. (2012; 2013). Speciation was calculated from the chemical composition of the experimental soil solutions at each sampling point.

\subsection{Microbiological analyses}

Soils are among the most diverse systems on Earth in terms of microbial diversity (Lozupone and Knight, 2007; Torsvik et al., 2002; Tringe et al., 2005). This means that it would have certainly been difficult to compare the bacterial composition of the soil to the bacterial composition of the slide and thus to compare the bacterial diversity in between the two systems in a robust manner. Hence, the slides were used as an ideal tool to reduce the soil community to the main active agents involved in the bioreduction of As-lepidocrocite. Here, the slides were used to only sample the bacteria likely to reduce $\mathrm{Fe}(\mathrm{III})$ and $\mathrm{As}(\mathrm{V})$ via their metabolic activities. The aim of the study was not to determine the entire bacterial biomass, but instead to follow the time-related dynamics of the biological reducing agents and the associated influence on $\mathrm{Fe}(\mathrm{II})$ and $\mathrm{As}$ (III) release within the interacting solution. To do this, a non-conventional tool was used to reduce the soil community to the true acting agents with regards to the studied processes.

\subsubsection{DNA extraction}


One slide for each sampling date (week 1 to week 8) was aseptically cut into pieces so as to fit loosely in the tubes provided in the Power Water DNA Isolation Kit (Mobio Laboratories, Carlsbad, CA), and the DNA was extracted following the manufacturer's recommendations.

\subsubsection{T-RFLP profiling}

T-RFLP profiling (Terminal Restriction Fragment Length Polymorphism) was conducted from slides collected at each incubation time. The 16S rRNA genes were amplified with $27 \mathrm{~F}$ and 1492R primers (Lane, 1991) labelled with FAM and HEX fluorochromes, cleaned with the GFX PCR DNA and Gel Band Purification kit (GE Healthcare) and digested with HaeIII and HinfI restriction endonucleases $\left(37^{\circ} \mathrm{C}, 3 \mathrm{~h}\right)$. T-RFLP profiles were obtained with a 310 genetic analyzer (Applied Biosystems) following the manufacturer's recommendations and analyzed with Genescan (Applied Biosystems).

\subsubsection{Gene amplification and library construction}

The 16S rRNA genes were amplified for the slides sampled at weeks 1, 3 and 8 and at weeks 3 and 8 for genes involved in As transformation (see Table A.1 - supporting information - for the primers used). PCR products, when present, were used to construct clone libraries using a TOPO TA cloning kit (vector pCR 2.1-TOPO, Invitrogen) according to the

manufacturer's instructions. Recombinant colonies were screened by PCR using primers M13R and T7, and inserts of the correct size were sequenced by GATC Biotech (Konstanz, Germany). Sequences were edited using Sequencher v4.1.4 (Gene Codes Corporation, MI, US). All DNA amplifications were performed in thermocyclers PTC 100 or PTC 200 (MJ research, USA). Each $50 \mu \mathrm{l}$ reaction contained $0.1 \mathrm{mM}$ of each $\mathrm{dNTP}, 0.4 \mu \mathrm{M}$ of each primer, x2 mix of Amplitaq Gold 360 (Applied Biosystems) and $5 \mu 1$ of DNA extract. See Fahy et al. (2015) for the PCR conditions.

\subsubsection{Clone libraries analyses}


Chimeras were eliminated using a combination of the Pintail and Mallard programs (Ashelford et al., 2006), and Greengenes (DeSantis et al., 2006). The coverage of the libraries at $97 \%$ similarity was calculated according to Good (1953). A comparison of the 16S rRNA libraries was carried out with Libcompare, RDP release 10 (Cole et al., 2009). Diversity studies were performed with Mothur (Schloss et al., 2009).

Coding sequences were translated prior to carrying out a BLAST analysis (Altschul et al., 1997) against the NCBI non-redundant protein sequence database (nr). Protein sequences were aligned with ClustalW2 (Larkin et al., 2007). Phylogenetic analyses were performed with MEGA v4 (Tamura et al., 2007), using the Neighbor-Joining method (Saitou and Nei 1987) and the Poisson correction model (Zuckerkandl and Pauling, 1965), pairwise deletion, and bootstrapping analysis (Felsenstein, 1985) from 1000 replicates.

\subsubsection{Nucleotide sequence accession numbers}

The DNA and protein sequences reported in this study were deposited in the EMBL database under the accession numbers HE804267 to HE804616 (16S rRNA gene), and HE804617 to HE804677 (arsB and ACR3(1)).

\section{RESULTS}

\subsection{Soil solution composition}

The data recording the evolution of the soil solution composition can be found in Table 2 and are displayed in Figs. 1a-d.

Through a classical reduction sequence in flooded soil, Eh rapidly decreased to $2 \mathrm{mV}$ in 1 week, and the lowest value was reached at week 6 at $-65 \mathrm{mV}$. At the end of the experiment, Eh increased to $-43 \mathrm{mV}$ (Fig. 1) reflecting the establishment of moderate reducing conditions. The $\mathrm{pH}$ increased to 7.15 and remained roughly constant throughout the experiment although it slightly increased up to 7.7 (Fig. 1a). This increase is explained by the 
$\mathrm{H}^{+}$consumption by the reducing reaction. Although the $\mathrm{SO}_{4}{ }^{2-}$ concentration was stable at the beginning of the experiment, it sharply decreased between week 1 and 2 to remain constant below the quantification limit ( $\mathrm{ql})\left(\mathrm{ql}=0.5 \mathrm{mg} \mathrm{L}^{-1}\right)$ (Fig. 1b). Iron(II) and acetate were produced as soon as the solution was $\mathrm{NO}_{3}{ }^{-}$depleted $\left(<\mathrm{ql}: 0.5 \mathrm{mg} \mathrm{L}^{-1}\right)$. Iron(II) and total $\mathrm{Fe}$ $\left(\mathrm{Fe}_{\mathrm{tot}}\right)$ exhibited the same behavior, suggesting that the released $\mathrm{Fe}$ only corresponded to Fe(II) (Fig. 1c). The maximum Fe(II) concentrations were $>34 \mathrm{mg} \mathrm{L}^{-1}$ after 4 weeks of incubation. The acetate concentration rose up to $91.2 \mathrm{mg} \mathrm{L}^{-1}$ at week 3 and then decreased to $5 \mathrm{mg} \mathrm{L}^{-1}$ after week 4 (Fig. 1b). Acetate and Fe(II) are by-products of the organic carbon consumption and Fe(III) oxides are used as an e- acceptor by soil bacteria for their growth, respectively. Dissolved organic carbon (DOC) concentrations quickly increased to reach a maximum of $364.3 \mathrm{mg} \mathrm{L}^{-1}$ at week 3, then decreased to $198.6 \mathrm{mg} \mathrm{L}^{-1}$ at week 6 , and reached $225 \mathrm{mg} \mathrm{L}^{-1}$ at the end of the experiment (Fig. 1b). Dissolved inorganic carbon (DIC) concentrations decreased from $12.1 \mathrm{mg} \mathrm{L}^{-1}$ to $6.2 \mathrm{mg} \mathrm{L}^{-1}$ between week 1 and 3 , and then increased again until week $6\left(16.7 \mathrm{mg} \mathrm{L}^{-1}\right)$ to reach $10.7 \mathrm{mg} \mathrm{L}^{-1}$ at the end of the experiment. The increase in DIC can be explained by the soil organic carbon mineralization by the soil bacteria community. Arsenic was released as soon as reductive conditions prevailed (Fig. 1d). Arsenic $(\mathrm{V})$ solubilization followed a two-stage trend with a rapid onset at the beginning of the experiment, whereas the As(III) concentrations were low. Then, As(V) reached a maximum at $53.3 \mu \mathrm{g} \mathrm{L} \mathrm{L}^{-1}$ at week 6 only to drastically drop to $15.3 \mu \mathrm{g} \mathrm{L} \mathrm{L}^{-1}$ between weeks 6 and 8 (Fig. 1d). Arsenic(III) release followed a three-stage-trend with a first onset at $21 \mu \mathrm{g} \mathrm{L}^{-1}$ at week 3, followed by a decrease to $9.7 \mu \mathrm{g} \mathrm{L}^{-1}$ at week 4. Finally, As(III) reached $46.6 \mu \mathrm{g} \mathrm{L}^{-1}$ at the end of the experiment (Fig. 1d). The change in the arsenic redox state is evidenced by the evolution of the $\mathrm{As}(\mathrm{III}) / \mathrm{As}(\mathrm{V})$ ratio from 0 to 3.05 at the end of the experiment (see Table 2).

\subsection{Modelling speciation data}


Since the low amount of newly formed minerals precluded any direct identification to be performed, the saturation indexes of possible Fe(II) secondary minerals were calculated, with respect to the equilibrium condition, using PHREEQC/Model VI (Fig. 2). At the end of the experiment, the solution was saturated with respect to siderite and hydroxy-green rust $\mathrm{Fe}(\mathrm{III})_{2} \mathrm{Fe}(\mathrm{II})(\mathrm{OH})_{8}(-0.5<$ Saturation Index $<0.5)$. It is interesting to note that their occurrences were inversely related to the organic matter-Fe(II) complexation (Fig. 2). Davranche et al. (2013) demonstrated by kinetic modelling that, in organic-rich wetlands, $\mathrm{Fe}(\mathrm{II})$-organic matter complexation strongly prevents the readsorption of $\mathrm{Fe}(\mathrm{II})$ and the subsequent precipitation of newly formed Fe(II) minerals. A major consequence of this process is the significant dissolution of the initial Fe(III)-oxides and the very low amounts of precipitated secondary minerals.

\subsection{Scanning Electron Microscope observations}

The slides exhibited major changes throughout time. After one week of incubation, the slides were characterized by needles of pristine lepidocrocite (crystals measuring 0.03- to 0.3$\mu \mathrm{m}$ long), not yet weathered, but already colonized by bacteria (Fig. 3b) in contrast to the pristine lepidocrocite (Fig. 3a). Some of the colonizing bacteria became encrusted within little crystals. At 4 weeks, the bacteria became more encrusted, whereas small gaps were developing (Fig. 3c). At 8 weeks, a thick biofilm covered the oxide (Fig. 3d), and a 3dimensional alteration was clearly recorded (Fig. 3d). At this stage of the experiment, the lepidocrocite showed a more connected structure characterized by highly misshapen crystals (Fig. 3e).

\subsection{Bacterial community structure and dynamics}

As pointed out by SEM observations (Figs. 3a-e), the slides were colonized by bacterial communities in initially reductive conditions. The clone libraries of the $16 \mathrm{~S}$ rRNA genes 
produced by the communities after 1,3 and 8 weeks with a coverage of $85 \%, 75 \%$ and $72 \%$, respectively (Table A.2, supporting information), could be used to define their composition (Table 3). At week 1, the coated As(V)-Lp oxide slides were mainly colonized by bacteria belonging to the Geobacter genus (Deltaproteobacteria) and Bacillus and Oxalophagus related genera (Firmicutes), each representing between 26 and $35 \%$ of the clone library. Overall, the most abundant phylum was that of Firmicutes with $72 \%$ of the clone library, followed by Deltaproteobacteria (26\%) with Geobacter as a single representative. Gammaproteobacteria and other unaffiliated clones represented less than $4 \%$ of the total clone library. At week 3, more than half of the clone library consisted of the Geobacter genus (54\%), the rest being mainly made up of Firmicutes (30\%), among which $10 \%$ were Bacillus and Oxalophagus, $8 \%$ were Thermincola and 5\% were Fervidicella related strains. Representatives of other phyla such as Alphaproteobacteria, Betaproteobacteria and Elusimicrobia represented less than $4 \%$ of the clone library. At week 8 , the species diversity had increased (Table 3 and Fig. 4) although the community was still dominated by the Geobacter genus (34\%). At that time, other representatives of Firmicutes, Alpha and Betaproteobacteria had also colonized the slides. Additionally, Acidobacteria Gp3, Actinobacteria, Verrucomicrobia class 3, Chloroflexi, and BRC1 representatives were cohabiting on the coated As(V)-Lp oxide slides. The Shannon diversity indices indicated that the bacterial diversity on the slide increased with the duration of the incubation $(1.74 \pm 0.22$, week $1 ; 2.32 \pm 0.31$, week 3 and $3.44 \pm 0.17$, week 8 ). The T-RFLP profiles of the $16 \mathrm{~S}$ rRNA genes communities incubated for 1, 2, 3, 4, 6 and 8 weeks complement the overview of the community dynamics throughout the experiment. Nine main T-RFs were detected throughout the experiment, although only four were maintained throughout the incubation, with changes in their relative abundance (Fig. A.2, supporting information). The coupling of the T-RF length to $16 \mathrm{~S}$ rRNA clone libraries revealed that these T-RFs included at least representatives 
of the following genera: Geobacter and Gordonibacter; Clostridium and Gracilibacter; Bacillus, Oxalophagus, Thermincola and Mitsuokella; Desulfosporinus and ElusimicrobiumBRC1. Starting from week 2, Sporomusa and Ktedonobacter progressively colonized the slides.

The library coverage of the ArsB deduced sequences (Table A.2, supporting information) indicated a good recovery of the diversity of this As(III) transporter for both weeks 3 and 8 . At all sampling points, most of the sequences retrieved (81\%) fell within cluster 1 (Fig. 5), which showed a high similarity (at least 97\% of the amino acid identity) with the ArsB sequence from Pseudomonas fluorescens (Gammaproteobacteria). Clusters 2 and 3 (13\% of the sequences) were related to that of Pseudomonas putida, but with a lower similarity (80 to 83\%). One sequence was highly related to the ArsB of another Gammaproteobacteria belonging to the genus Shewanella, whereas two other sequences showed similarity to the ArsB of the Betaproteobacteria Comamonas testosteroni. The latter three sequences were solely retrieved at week 3 .

At week 3, the percentage of the Acr3(1)p library (79\%) indicated a good recovery of the diversity, whereas a similar number of clones at week 8 led to just less than $50 \%$ of coverage (Table A.2, supporting information) indicating an enrichment of the community on the slide. BLAST searches showed that most of the sequences retrieved (cluster 1) were close to the Geobacter Acr3(1)p sequences (similarity between 80 and 92\%) (Fig. 5). These sequence types were more frequently found at week $3(78 \%)$ than at week $8(47 \%)$. Other abundant sequences were found in clusters 2 and 3 and cluster 7, which respectively harbored sequences related to the Methylomicrobium album (Gammaproteobacteria) and Thermincola potens (Clostridia) ACR3(1) genes. Four other sequence types were present in the library, closely related to Acetonema longum, Desulfosporosinus meridiei (Clostridia), Desulfovibrio (Deltaproteobacteria), and Methanocella arvoryzae (Euryarchaea) ACR3(1). 
No PCR amplification was obtained for the arsenite oxidase genes. Faint amplifications were obtained for the arsenate reductase genes at weeks 3 and 8 with Malasarn's primers (Malasarn et al., 2004). Although very faint, the amplification product was slightly stronger at week 8 (Table A.1, supporting information).

\section{DISCUSSION}

\subsection{Reductive biodissolution}

The chemical dynamics of the soil solution depict a typical reduction sequence for water-saturated soil (Ponnamperuma, 1972). Whereas Grybos et al. (2009) demonstrated that the large DOC release was provided by the organic matter desorption from the soil in response to an increase in $\mathrm{pH}$ accompanied by reduction reactions, here, the increase in $\mathrm{pH}$ remained small. Therefore, the DOC release has to be related either to reductive dissolution leading to the release of organic matter bound to oxides and/or to DOC genesis by the soil reducing-bacterial biomass (Ponnamperuma, 1972; Lovley, 1991).

Week 6 is critical since a decrease in Fe(II) and acetate and an increase in As were recorded (Fig. 1). Experimental and field studies, in which decreases in aqueous Fe were observed, suggested the precipitation of secondary Fe(II) phases such as siderite, magnetite or vivianite (He et al., 1996; Zachara et al., 2002). To test this assumption, modelling calculations were performed to calculate the saturation index of such Fe(II)-minerals in the present organic-rich solutions (Fig. 2). Several Fe(II) phases seem to be saturated or supersaturated in solution, suggesting the precipitation of such solids from week 6, which could explain the observed decrease in Fe(II) (Fig. 1c). The drop in Fe(II) is concomitant to that of acetate. However, whereas the Fe(II) concentration stops decreasing between weeks 6 and 8 , the acetate concentration continued to decrease after week 6 . The precipitation of Ferich byproducts is supposed to strongly limit or inhibit electron shuttling between Fe(III) 
oxides and bacteria cells (Urrutia et al., 1998; Roden, 2004; 2006). The rate of electron transfer is the rate-limiting step during enzymatic reduction. The decrease in acetate may be a consequence of the secondary phase precipitation. The decrease in dissolved acetate, commonly used by dissimilatory Fe-reducing bacteria (DIRB), is interesting and would not have been observed if fermenting bacteria were present at a much higher abundance than the DIRB in the bacterial community as shown by Burnol et al. (2007). As described in the partial equilibrium model developed by Postma and Jacobsen (1996), respiration is generally sufficiently fast in relation to fermentation.

\subsection{Iron and As release rates}

The reductive dissolution of $\mathrm{As}(\mathrm{V})$ lepidocrocite would result in a concomitant release of As and Fe. However, Fe(II) and As solubilization were slightly decoupled at the beginning of the experiment (Fig. 1). This slightly delayed As solubilization was previously explained by the readsorption of $\mathrm{As}(\mathrm{V})$ onto residual ferrihydrite by Burnol et al. (2007) in a biotic case and by Pedersen et al. (2006) in an abiotic case. This hypothesis was also supported by Kocar et al. (2006) who experimentally showed the occurrence of As sequestration rather than desorption during the reductive dissolution of As-bearing ferrihydrite. Through ferrihydrite reduction experiments, Tufano and Fendorf (2008) established that at the beginning of Fe reduction, the resulting Fe secondary minerals increased As(III) retention, whilst with increasing reaction time, the ensuing reductive dissolution generated a significant As(III) release into solution. However, another hypothesis can be proposed suggesting that $\mathrm{Fe}(\mathrm{III})$ and $\mathrm{As}(\mathrm{V})$ were probably used sequentially by the biomass following the energy yield of each reaction. Burnol et al. (2007) suggested that $\mathrm{As}(\mathrm{V})$ is not reduced whilst the more energetically favorable Fe reduction dominated. However, based on thermodynamic data, Kocar and Fendorf (2009) demonstrated that $\mathrm{As}(\mathrm{V})$ reduction is more favorable than Fe(III) 
reduction across a range of As, acetate concentrations and circumneutral $\mathrm{pH}$. The Gibbs free energies $\left(\Delta \mathrm{G}_{\mathrm{r}}\right)$ of the present system were therefore calculated through time using the concentration gradients of $\mathrm{Fe}(\mathrm{II}), \mathrm{As}(\mathrm{V})$ and $\mathrm{As}(\mathrm{III})$ in the experiment. The total soil $\mathrm{Fe}$ content or the highest solubilized Fe(II) concentrations were considered as the Fe source. The produced acetate was used as the source of the labile $\mathrm{C}$. The calculations were performed considering $\mathrm{Fe}(\mathrm{III})$ and $\mathrm{As}(\mathrm{V})$ as $\gamma$ - $\mathrm{FeOOH}$ (Lepidocrocite) or $\mathrm{Fe}(\mathrm{OH})_{3}$, and as $\mathrm{HAsO}_{4}{ }^{2-}$ or $\mathrm{H}_{2} \mathrm{AsO}_{4}{ }^{-}$, respectively. $\Delta \mathrm{G}_{\mathrm{r}}$ varied from -92.6 to $155 \mathrm{Kj} \mathrm{mol}^{-1}$ and from -228.6 to $-270.3 \mathrm{Kj}$ $\mathrm{mol}^{-1}$ for the $\mathrm{Fe}(\mathrm{III})$ and $\mathrm{As}(\mathrm{V})$ reduction, respectively (Fig. A.3, supporting information). Therefore, in our experimental conditions, As reduction was always energetically more favorable for respiratory bacteria than Fe(III) reduction. In contrast to Burnol et al.'s hypothesis (2007), the different release rates of Fe and As observed were thus probably less related to the energy provided by the reducing respiratory reactions than by the limited As availability. Arsenic is first bound to Fe-oxides and is subsequently partially readsorbed until the Fe-oxides are sufficiently dissolved or trapped in secondary minerals, as previously suggested by Pedersen et al. (2006) and Tufano and Fendorf (2008).

These different release rates might also be related to the amount and quality of the labile organic carbon supply directly linked to the prevailing bacterial community. Previous laboratory and field experiments, such as that of Mailloux et al. (2009), suggested that As release could occur during fermentation, Fe(III) reduction, and methanogenesis when an adequate supply of organic carbon is provided. Subsequently, Mailloux et al. (2009) proposed that nutrient limitation is the key parameter controlling the As release rate and that often ancillary arsenic release has been obscured by the overprint of iron cycling. Considering that fermentative bacteria (Firmicutes) were evidenced, any contribution to the As release sourced in the fermentative bacteria metabolism cannot be completely precluded, even though $\mathrm{Fe}$ reducing bacteria also resulted, through $\mathrm{Fe}(\mathrm{III})$ reduction, in Fe and As solubilization. 


\subsection{The bacterial communities involved}

At the end of the first week of incubation, Geobacter Fe-reducing bacteria, and fermentative Firmicutes, particularly Bacillus and Oxalophagus-related taxa, were the first and dominant colonizers on the coated As(V)-Lp oxide slides. Apart from these taxa, a cortege composed of various Clostridia- and Pseudomonas-related organisms completed the assemblage (Table 4). The occurrence of these organisms is coherent with the composition of the soil solution (Lovley, 1993). The increase in acetate may result from the fermentative process mediated by fermentative bacteria (Bacillus-, Clostridium-, Fervidicella-, Gracilibacter-, Sporotalea-related strains), whereas Fe(III) reduction can be efficiently ensured by Geobacter-related species even though some fermentative bacteria can also conserve energy from this process (Carlson et al., 2012; Slobodkin, 2005; Wrighton et al., 2011). Acetate is thus completely oxidized to carbon dioxide with Fe(III) serving as the sole electron acceptor. This sequence of cooperative activities between fermentative microorganisms and dissimilatory $\mathrm{Fe}(\mathrm{III})$ reducing microorganisms fits the model of microbially catalyzed oxidation of organic matter coupled to $\mathrm{Fe}(\mathrm{III})$ reduction proposed by Lovley (1993).

After week 3, the richness of the community increased to comprise other fermentative bacteria, another group of Clostridium (Firmicutes) and Elusimicrobium (Elusimicrobia), in addition to an acetogenic bacteria, a Sporomusa-related strain, which may sustain acetate production, whereas the abundance of the Bacillus- and Oxalophagus-related strains decreased. Interestingly, another colonizer related to Thermincola (Firmicutes) was detected, whereas the abundance of Geobacteraceae still increased. Thermincola can reduce amorphous $\mathrm{Fe}(\mathrm{III})$-hydroxide and oxidize hydrogen and acetate using $\mathrm{Fe}(\mathrm{III})$ as a terminal electron acceptor (Zarvazina et al., 2007). Although the community was at that time imprinted by the anoxic conditions, we noticed the minor presence of (micro)aerobic organisms, such as 
Sphingomonas (Alphaproteobacteria), a versatile chemoorganotroph microorganism able to use diverse carbon sources, and Ralstonia (Betaproteobacteria), a genus able to thrive on hydrogen as a sole source of energy (Bowien and Schlegel, 1981; Lenz et al., 2002).

At week 8, whereas a decline in acetate and DOC prevailed in the solution, the increase in diversity still progressed with the appearance, each in low abundance, of less specialized microorganisms with regards to $\mathrm{Fe}(\mathrm{III})$ reduction. Iron-reducing bacteria still persisted on the slide, but to a lesser extent. This observation reflected the varied environment that was established over time by the pioneer microorganisms. Conditions on the slides became more favorable to other metabolic groups (e.g. Acidobacteria, Actinobacteria, Chloroflexi), whereas the acetate limitation impaired the growth of Geobacter-related strains.

At the beginning of the experiment, the sulfate concentration decreased to below the detection level, although no sulfate reducing bacteria were clearly identified. However, recent studies have suggested that our knowledge of this functional group is still limited, and we might have failed to detect these organisms. Pester et al. (2010) showed that even at very low abundance $(0.006 \%$ relative $16 \mathrm{~S}$ rRNA gene abundance), some bacteria could carry out sulfate reduction in peatlands. In addition, bacteria harboring $d s r A B$ genes (encoding subunits A and B of dissimilatory (bi)sulfite reductase) have been detected in various environments including wetlands, even though they were not related to known SRBs, and no correlation with the sulfate reduction could be confidently inferred (Pester et al., 2012).

\subsection{Focus on biotic agents of As redox behavior}

Arsenic(V) can be subjected to two microbially-mediated reductive processes: detoxification and/or dissimilatory reduction. Two main families of arsenite transporters involved in the detoxification of As by the cells have been identified: ArsB and Acr3p, itself subdivided into Acr3(1)p and Acr3(2)p (Rosen, 1999; Achour et al., 2007). Bacteria that are resistant to As often have one or two genes encoding for these transporters (Achour et al., 
2007). The presence of ArsB and Acr3(1)p transporter encoding genes (genes for Acr3(2)p transporters were not detected) involved in the detoxification were found in the community at week 3 and 8 , indicating that this community harbored arsenic-resistant or arsenictransforming genera potentially able to transform the released As(V) into As(III). Yet, the horizontal transfer of arsenite transporter encoding genes (at least $\operatorname{ars} B$ and $A C R 3(2)$ ) between strains suggested by Cai et al. (2009) indicates that caution should be taken when assigning a sequence type to a genus. However, it is reasonable to think that some of these genes are harbored by species identified in the $16 \mathrm{~S}$ phylogenetic approach: e.g. ACR3(1) genes from Geobacter, Thermincola, Desulfosporosinus or arsB gene from Pseudomonas even though some of them could have been spread in the community by horizontal transfer. No strains related to Acetonema, Desulfovibrio and Methylomicrobium or Shewanella and Comamonas were detected by the $16 \mathrm{~S}$ phylogenetic diversity analyses, whereas the $A C R 3(1)$ and ars $B$ gene sequences closely related to those found in these genera were detected. This observation could eventually reflect cases of horizontal gene transfer although we cannot rule out that these taxa, perhaps less dominant, were not detected in our library. At any time of sampling, the richness of the Acr3(1)p transporters was greater than that of ArsB (the PCR product of the $\operatorname{ars} B$ gene was low). This result is consistent with the observations of Achour et al. (2007), who suggested that the Acr3p family of arsenite transporters may be more widespread in bacteria than ArsB.

In contrast to nested PCR, direct PCR avoids biases in the representativeness of the targeted genes. We adopted this latter approach to target the $\operatorname{arrA}$ gene involved in the dissimilatory reduction of As. Unfortunately, the faint PCR product obtained with Malasarn's primers precluded the construction of $\operatorname{arr} A$ gene libraries to identify $\operatorname{arr} A$-bearing strains. Some of the phylogenetic groups detected in the $16 \mathrm{~S}$ gene library have been shown, at least for some strains, to harbor arrA genes: e.g. Desulfosporosinus sp. Y5 (Pérez-Jiménez et al., 
2005), Bacillus with B. selenitireducens (Afkar et al., 2003) and B. arseniciselenatis (Duval et al., 2008; Malasarn et al., 2004) or Clostridium with $C l$. sp. OhilAs, $C l$. sp. ARCL1 and $C l$. sp. AKAR3 (Oremland and Stolz, 2003; Rhine et al., 2005). Additionally, Geobacter with G. loveyii (Duval et al., 2008) and G. uranireducens (Giloteaux et al., 2013) and an identified strain belonging to Clostridium, $C l$ sp. FRB1 (Burnol et al., 2007), have the capacity to use both $\mathrm{As}(\mathrm{V})$ and $\mathrm{Fe}(\mathrm{III})$ as electron acceptors to respire.

However, although these genera are good candidates, we cannot ascertain for certain that the strains detected in our study harbored this gene. Interestingly, a close examination of the sequence targeted by Malasarn's primers revealed a poor match with the Geobacter arrA gene (data not shown). It may be that the faint arrA PCR product detected belonged to another genus (or genera). Alternatively, the faint amplification of the arrA gene could indicate that dissimilatory arsenate-reducing bacteria were poorly represented in the community. In any case, we have to admit that the identification of DARB (or DARP) in the environment is rarely assessed and is still a challenge. Efforts have to be made to improve our capacity to detect these organisms using direct PCR approaches, which is essential to identify the true actors involved in the biogeochemical dynamics of As. This will also allow researchers to go one step further to tease apart the role of detoxifying or respiratory processes in $\mathrm{As}(\mathrm{V})$ reduction by providing useful primers to target directly the transcripts of these genes through quantitative PCR.

Thus, this study suggests that the soils from the Mercy wetland harbor bacteria with the capacity to reduce $\mathrm{As}(\mathrm{V})$ either as the result of resistance involving the arsenite transporter ArsB or through dissimilatory respiration. The presence of arsenite oxidase coding genes was not detected (data not shown), which is consistent with the prevailing anaerobic environment of the slides and the increasing concentration of the released As(III).

\section{CONCLUSIONS}


As soon as the incubation began, the As(V)-doped lepidocrocite slides were colonized by bacteria, which were identified as Bacillus and Oxalophagus fermentative bacteria and Geobacter Fe-reducing bacteria. The first bacterial species produced the acetate necessary for the growth of the second species. This colonization was therefore accompanied by a solubilization of $\mathrm{Fe}(\mathrm{II})$ and $\mathrm{As}(\mathrm{III})$ in solution and the formation of 3-dimensionally shaped biodissolution of lepidocrocite on the slides. However, the release of $\mathrm{Fe}(\mathrm{II})$ and As was delayed, which can be explained by the precipitation of Fe(II) secondary minerals able to trap As $(V)$, and the amount and quality of the available organic carbon. The diversity of the bacteria community increased throughout the incubation time and although it was dominated by the Geobacter genus at week 8 , the new colonizing microorganisms were less specialized in Fe-oxide reduction, which resulted in the decrease in acetate production and $\mathrm{Fe}(\mathrm{II})$ release. The As data showed that both $\mathrm{As}(\mathrm{V})$ release and its reduction to As(III) were initiated during the first week alongside Fe(III) reduction. The presence of ArsB and Acr3(1)p transporters encoding genes - involved in the detoxification processes - found in the community at weeks 3 and 8 indicated that this community at least harbored arsenic-resistant genera able to transform the dissolved released As(V) into As(III).

\section{ACKNOWLEDGEMENTS}

This study was funded by the CNRS-INSU EC2CO/CYTRIX program, and by the French ANR, through the "Programme Jeunes Chercheurs": ARSENORG. Dr S. Mullin is acknowledged for post-editing the English style.

\section{REFERENCES}

Achour, A.R., Bauda, P., Billard, P., 2007. Diversity of arsenite transporter genes from arsenic-resistant soil bacteria. Research Microbiology 158, 128-137. 
Afkar, E., Lisak, J., Saltikov, C., Basu, P., Oremland, R.S., Stolz, J.F., 2003. The respiratory arsenate reductase from Bacillus selenitireducens strain MLS10. FEMS Microbiological Letters 226, 107-112.

AFNOR, 1997. Qualité de l'Eau, Méthodes d'Analyses 2, vol.3. Elément Majeurs; Autres Eléments et Composés Minéraux, AFNOR, Paris.

AFNOR, 2004. Evaluation de la qualité des sols, vol.1. Méthodes d'analyse chimique, AFNOR, La Plaine saint-Denis, 461pp.

Altschul, S.F., Madden, T.L., Schäffe, A.A., Zhang, J., Zhang, Z., Miller, W., Lipman, D.J., 1997. Gapped BLAST and PSI-BLAST: A new generation of protein database search programs. Nucleic Acids Research 25, 3389-3402.

Ashelford, K.E., Chuzhanova, N.A., Fry, J.C., Jones, A.J., Weightman, A.J., 2006. New screening software shows that most recent large $16 \mathrm{~S}$ rRNA gene clone libraries contain chimeras. Applied Environmental Microbiology 72, 5734-5741.

Avena, M.J., Koopal, L.K., 1999. Kinetics of humic acid adsorption at solid-water interfaces. Environmental Science \& Technology 33, 2739-2744.

Birkefeld, A., Schulin, R., Nowack, B., 2005. A new in situ method to analyze mineral particle reactions in soils. Environmental Science \& Technology 39, 3302-3307.

Bonneville, S., Cappellen, P.V., Behrends T., 2004. Microbial reduction of iron (III) oxyhydroxides: effects of mineral solubility and availability. Chemical Geology 212, 255268.

Bose, P., Sharma, A., 2002. Role of iron in controlling speciation and mobilization of arsenic in subsurface environment. Water Research 36, 4916-4926.

Bousserrhine, N., Gasser, U.G., Jeanroy, E., Berthelin, J., 1999. Bacterial and Chemical Reductive Dissolution of Mn-, Co-, Cr-, and Al-Substituted Goethites. Geomicrobiology Journal 16, 245-258.

Bowien, B., Schlegel, H.G., 1981. Physiology and biochemistry of aerobic hydrogenoxidizing bacteria. Annual Review of Microbiology 35, 405-452.

Brown, G.E.J., Sturchio, N.C., 2002. An overview of synchrotron radiation application to low-temperature geochemistry and environmental science. In: P.A. Fenter (Editor), Application of synchrotron radiation in low-temperature geochemistry and environmental science. Reviews in Mineralogy and Geochemistry 49, 1-107.

Burnol, A., Garrido, F., Baranger, P., Joulian, C., Dictor, M.C., Bodénan, F., Morin, G., Charlet, L., 2007. Decoupling of arsenic and iron release from ferrihydrite suspension under reducing conditions: a biogeochemical model. Geochemical Transactions 29, 8-12.

Cai, L., Liu, G., Rensing, C., Wang, G., 2009. Genes involved in arsenic transformation and resistance associated with different levels of arsenic-contaminated soils. BMC Microbiology 9, 4.

Cancès, B., Juillot, F., Morin, G., Laperche, V., Alvarez, L., Proux, O., Hazemann, J.-L., Brown, Jr. G.E., Calas, G., 2005. XAS evidence of $\mathrm{As}(\mathrm{V})$ association with iron 
oxyhydroxides in a contaminated soil at a former arsenical pesticide processing plant. Environmental Science \& Technology 39, 9398-9405.

Cancès, B., Juillot, F., Morin, G., Laperche, V., Polya, D., Vaughan, D.J., Hazemann, J.L., Proux, O., Brown, Jr. G.E., Calas, G., 2008. Change in arsenic speciation through a contaminated soil profile: a XAS based study. Science of the Total Environment 397, 178189.

Carlson, H.K., Iavarone, A.T., Gorur, A., Yeo, B.S., Tran, R., Melnyk, R.A., Mathies, R.A. Aue, M, Coates, J.D., 2012. Surface multi heme c-type cytochromes from Thermincola potens and implications for respiratory metal reduction by Gram-positive bacteria. Proceedings of the National Academy of Sciences 109, 1702-1707.

Charlatchka, R., Cambier, P., 2000. Influence of reducing conditions on solubility of trace metals in contaminated soils. Water, Air and Soil Pollution 118, 143-167.

Chuan, M.C., Shu, G.Y., Liu, A., 1996. Solubility of heavy metals in a contaminated soil: effect of redox potential and pH. Water, Air and Soil Pollution 90, 543-556.

Coker, V.S., Gault, A.G., Pearce, C.I., Van der Laan, G., Telling, N.D., Charnock, J.M., Polya, D.A., Lloyd, J.R., 2006. Environ. XAS and XMCD evidence for species-dependent partitioning of arsenic during microbial reduction of ferrihydrite to magnetite. Environmental Science \& Technology 40, 7745-7750.

Cole, J.R., Wang, Q., Cardenas, E., Fish, J., Chai, B., Farris, R.J., Kulam-Syed-Mohideen, A.S., McGarrell, D.M., Marsh, T., Garrity, G.M., Tiedje, J.M., 2009. The Ribosomal Database Project: improved alignments and new tools for rRNA analysis. Nucleic Acids Research 37, 141-145.

Cooper, D.C., Picardal, F., Rivera, J., Talbot, C., 2000. Zinc immobilization and magnetite formation via ferric oxide reduction by Shewanella putrefaciens 200. Environmental Science \& Technology 34, 100-106.

Cornell, R.M., Schwertmann, U., 2003. The Iron Oxides: Structure, Properties, Reactions, Occurrence and Uses. VCH. Weinheim.

Curmi, P., Bidois, J., Bourrié, G., Cheverry, C., Durand, P., Gascuel-Odoux, C., Germon, J.C., Hallaire, V., Hénault, C., Jaffrezic, A., Mérot, P., Trolard, F., 1997. Rôle du sol sur la circulation et la qualité des eaux au sein de paysages présent en domaine hydromorphe. Etude et gestion des sols 4, 95-111.

Davranche, M., Bollinger, J.-C., 2000. Heavy Metals Desorption from Synthesized and Natural Iron and Manganese Oxyhydroxides: Effect of Reductive Conditions. Journal of Colloid and Interface Science 227, 531-539.

Davranche, M., Bollinger, J.-C., 2001. A desorption-dissolution model for metal release from polluted soil under reductive conditions. Journal of Environmental Quality 30, 1581-1586.

Davranche, M., Bollinger, J.-C., Bril, H., 2003. Effect of reductive conditions on metal mobility from wasteland solids: an example from the Mortagne-du-Nord site (France). Applied Geochemistry 18, 383-394.

Davranche, M., Pourret, O., Gruau, G., Dia, A., 2004. Impact of humate complexation on the adsorption of REE onto Fe oxyhydroxide. J. Colloid Interface Sci. 277, 271-279. 
Davranche, M., Grybos, M., Gruau, G., Pédrot, M., Dia, A., Marsac, R., 2011. Rare earth element patterns: A tool for identifying trace metal sources during wetland soil reduction. Chemical Geology 284, 127-137.

Davranche, M., Dia, A., Fakih, M., Nowack, B., Gruau, G., Ona Nguema, G., Petitjean, P., Martin S., Hochreutener, R., 2013. Organic matter control on the reactivity of Fe(III)oxyhydroxides and associated As in wetland soils: A kinetic modeling study. Chemical Geology 335, 24-35.

DeSantis, T.Z., Hugenholtz, P., Larsen, N., Rojas, M., Brodie, E.L., Keller, K., Huber, T., Dalevi, D., Hu, P., Andersen, G.L., 2006. Greengenes, a chimera-checked 16S rRNA gene database and workbench compatible with ARB. Applied and Environmental Microbiology 72, 5069-5072.

Dia, A., Gruau, G., Olivié-Lauquet, G., Riou, C., Molénat, G., Curmi, P., 2000. The distribution of rare earth elements in groundwaters: Assessing the role of source-rock composition, redox changes and colloidal particles. Geochimica et Cosmochimica Acta 64, 4131-4151.

Dixit, S., Hering, J.G., 2003. Comparison of arsenic(V) and arsenic(III) sorption onto iron oxide minerals: implications for arsenic mobility. Environmental Science \& Technology 37, 4182-4189.

Duval, S., Ducluzeau, A.L., Nitschke, W., Schoepp-Cothenet, B., 2008. Enzyme phylogenies as markers for the oxidation state of the environment: The case of respiratory arsenate reductase and related enzymes. BMC Evolutionary Biology 8, 206.

Fahy, A., Giloteaux, L., Bertin, P., Le Paslier, D., Médigue, C., Weissenbach, J., Duran, R., Lauga, B., (2015). 16S rRNA and As-Related Functional Diversity: Contrasting Fingerprints in Arsenic-Rich Sediments from an Acid Mine Drainage. Microbial Ecology, DOI: $10.1007 / \mathrm{s} 00248-014-0558-3$.

Fakih, M., Davranche, M., Dia, A., Nowack, B., Petitjean, P., Châtellier, X., Gruau, G., 2008. A new tool for in situ monitoring of Fe-mobilization in soils. Applied Geochemistry 23, $3372-3383$.

Fakih, M., Davranche, M., Dia, A., Nowack, B., Morin, G., Petitjean, P., Châtellier, X., Gruau, G., 2009. Environmental impact of As(V)-Fe oxyhydroxide reductive dissolution: an experimental insight. Chemical Geology 259, 290-303.

Felsenstein, J., 1985. Confidence limits on phylogenies: an approach using the bootstrap. Evolution 39, 783-791.

Francis, A.J., Dodge, C.J., 1990. Anaerobic Microbial Remobilization of Toxic Metals Coprecipitated with Iron Oxide. Environmental Science \& Technology 24, 373-378.

Giloteaux, L., Holmes, D.E., Williams, K.H., Wrighton, K.C., Wilkins, M.J., Montgomery, A.P., Smith, J.A., Orellana, R., Thompson, C.A., Roper, T.J., Long, P.E., Lovley, D.R., 2013. Characterization and transcription of arsenic respiration and resistance genes during in situ uranium bioremediation. ISME Journal 7, 370-383. 
Glasauer, S., Weidler, P.G., Langley, S.L., Beveridge, T.J., 2003. Controls on Fe reduction and mineral formation by a subsurface bacterium. Geochim. Cosmochim. Acta 67, 12771288

Good, I.J., 1953. The population frequencies of species and the estimation of population parameters. Biometrika 40, 237-264.

Green, C.H., Heil, D.M., Cardon, G.E., Butters, G.L., Kelly, E.F., 2003. Solubilization of Manganese and Trace Metals in Soils Affected by Acid Mine Runoff. Journal of Environmental Quality 32, 1323-1334.

Grybos, M., Davranche, M., Gruau, G., Petitjean, P., 2007. Is trace metal release in wetland soils controlled by organic matter mobility or Fe-oxyhydroxides reduction? Journal of Colloid and Interface Science 314, 490-501.

Grybos, M., Davranche, M., Gruau, G., Petitjean, P., Pédrot, M., 2009. Increasing pH drives the release of organic matter from wetlands soils under reducing conditions. Geoderma $154,13-19$.

He, Q.H., Leppard, G.G., Paige, C.R., Snodgrass, W.J., 1996. Transmission electron microscopy of a phosphate effect on the colloid structure of iron hydroxide. Water Research 30, 1345-1352.

Islam, F.S., Gault, A.G., Boothman, C., Polya, D., Chatterjee, D., Lloyd, J.R., 2004. Role of metal-reducing bacteria in arsenic release from Bengal delta sediments. Nature 430, 68-71.

Jenkinson, B.J., Franzmeier, D.P., 2006. Development and Evaluation of Iron-Coated Tubes that Indicate Reduction in Soils. Soil Science Society of America Journal 70, 183-191.

Jönsson, J., Sherman, D.M., 2008. Sorption of As(III) and As(V) to siderite, green rust (fougerite) and magnetite: implications for arsenic release in anoxic groundwaters. Chemical Geology 255, 173-181.

Jorgensen, S.S., Willems, M., 1987. The fate of lead in soils - the transformation of lead pellets in shooting-range soils. Ambio 16, 11-15.

Kocar, B.D., Herbel, M.J., Tufano, K.J., Fendorf, S., 2006. Contrasting effects of dissimilatory iron(III) and $\operatorname{arsenic}(\mathrm{V})$ reduction on arsenic retention and transport. Environmental Science \& Technology 40, 6715-6721.

Kocar, B.D., Fendorf, S., 2009. Thermodynamic constraints on reductive reactions influencing the biogeochemistry of arsenic in soils and sediments. Environmental Science \& Technology 43, 4871-4877.

Lane, D.J., 1991. rDNA sequencing. In Nucleic acid techniques in bacterial systematics. Stachenbrady, E. (ed). Chichester: Wiley: 115-175.

Larkin, M.A., Blackshields, G., Brown, N.P., Chenna, R., McGettigan, P.A., McWilliam, H., Valentin, F., Wallace, I.M., Wilm, A., Lopez, R., Thompson, J.D., Gibson, T.J., Higgins, D.G., 2007. Clustal W and clustal X version 2.0. Bioinformatics 23, 2947-2948.

Lenz, O., Bernhard, M., Buhrke, T., Schwartz, E., Friedrich, B., 2002. The hydrogen-sensing apparatus in Ralstonia eutropha. Journal of Molecular Microbiology and Biotechnology 4, 255-262. 
Lloyd, J.R., Oremland, R.S., 2006. Microbial transformations of arsenic in the environment: From soda lakes to aquifers. Elements 2, 85-90.

Lovley, D.R., Phillips, E.J.P., 1986. Availability of Ferric Iron for Microbial Reduction in Bottom Sediments of the Freshwater Tidal Potomac River. Applied and Environmental Microbiology 52, 751-757.

Lovley, D.R., Stolz, J.F., Nord, G.L. Jr., Phillips, E.J.P., 1987. Anaerobic production of magnetite by dissimilatory iron-reducing microorganism. Nature 330, 420-434.

Lovley, D.R., 1991. Dissimilatory Fe(III) and Mn(IV) reduction. Microbiological Reviews $55,259-287$.

Lovley, D.R., Phillips, E.J.P., Lonergan, D.L., 1991. Enzymatic versus non enzymatic mechanisms for $\mathrm{Fe}(\mathrm{III})$ reduction in aquatic sediments. Environmental Science \& Technology 25, 1062-1067.

Lovley, D.R., 1993. Anaerobes into Heavy-Metal - Dissimilatory Metal Reduction in Anoxic Environments. Trends in Ecology and Evolution 8, 213-217.

Lovley, D.R., 1997. Microbial Fe(III) reduction in subsurface environments. FEMS Microbiology Reviews 20, 305-313.

Lovley, D.R., Coates, J.D., 1997. Bioremediation of metal contamination. Current Opinion in Biotechnology 8, 285-289.

Lovley, D.R., 2006. Dissimilatory Fe(III)- and Mn(IV)-reducing Prokaryotes. In Prokaryotes, Springer, 1194 p, 635-658.

Lozupone, C.A., Knight, R., 2007. Global patterns in bacterial diversity. Proceedings of the National Academy of Sciences 104, 11436-11440.

McBride, M.B., 1994. Environmental Chemistry of Soils. New York: Oxford University Press. 406 p.

Mailloux, B.J, Alexandrova, E., Keimowitz, A.R., Wovkulich, K., Freyer, G.A., Herron, M., Stolz, J.F., Kenna, T.C., Pichler, T., Polizzotto, M.L., Dong, H., Bishop, M., Knappett, P.S.K., 2009. Microbial weathering for nutrient acquisition releases arsenic. Applied and Environmental Microbiology 75, 2558-2565.

Malasarn, D., Saltikov, C.W., Campbell, K.M., Santini, J.M., Hering, J.G., Newman, D.K., 2004. $\operatorname{arrA}$ is a reliable marker for As(V) respiration. Science 306, 455.

Manning, B.A., Fendorf, S.E., Goldberg, S., 1998. Surface structures and stability of arsenic(III) on goethite: spectroscopic evidence for inner sphere complexes. Environmental Science \& Technology 32, 2383-2388.

Marsac, R., Davranche, M., Gruau, G., Dia, A., Bouhnik-Le Coz, M., 2011. An improved description of the interactions between rare earth elements and humic acids by modeling: PHREEQC-Model VI coupling. Geochimica et Cosmochimica Acta 75, 5625-5637. 
Marsac, R., Davranche, M., Gruau, G., Dia, A., Bouhnik-Le Coz, M., 2012. Aluminium competitive effect on rare earth elements binding to humic acid. Geochimica et Cosmochimica Acta 89, 1-9.

Marsac, R., Davranche, M., Gruau, G., Dia, A., Pédrot, M., Le Coz-Bouhnik, M., Briant, N., 2013. Effects of Fe competition on REE binding to humic acid: Origin of REE pattern variability in organic waters. Chemical Geology 342, 119-127.

Masscheleyn, P.H., Delaune, R.D., Patric, W.H., 1991. A hydride generation atomicabsorption technique for arsenic speciation. Journal of Environmental Quality 20, 96-100.

Michon, J., 2006. Etude de l'oxydation biologique de l'As(III) par le consortium bactérien CAsO1: mise au point de méthodes de détection et application à la détoxification des effluents. Ph.D thesis, University of Limoges (France), 283 pp.

Morin, G., Ostergren, J., Juillot, F., Ildefonse, P., Calas, G., Brown, G.E.J., 1999. XAFS determination of the chemical form of lead in smelter-contaminated soils and mine tailings: importance of sorption processes. American Mineralogist 84, 420-434.

Morin, G., Lecocq, D., Juillot, F., Calas, G., Ildefonse, P., Belin, S., Briois, V., Dillmann, P., Chevallier, P., Gauthier, C., Sole, A., Petit, P.E., Borensztajn, S., 2002. EXAFS evidence of sorbed arsenic $(\mathrm{V})$ and pharmacosiderite in soil overlying the Eschassières geochemical anomaly, Allier, France. Bulletin de la Société Géologique de France 173, 281-291.

Morin, G., Calas, G., 2006. Arsenic in soils, mine tailings, and former industrial sites. Elements 2, 97-101.

Mossop, K.F., Davidson, C.M., 2003. Comparison of original and modified BCR sequential extraction procedures for the fractionation of copper, iron, lead, manganese and zinc in soils and sediments. Analytica Chimica Acta 478, 111-118.

Nickson, R.T., McArthur, J.M., Ravenscroft, P., Burgess, W., Ahmed, K.M., 2000. Mechanism of arsenic release to groundwater, Bangladesh and West Bengal. Applied Geochemistry 15, 403-413.

Olivié-Lauquet, G., Gruau, G., Dia, A., Riou, C., Jaffrezic, A., Henin, O., 2001. Release of trace elements in wetlands: role of seasonal variability. Water Research 35, 943-952.

Ona-Nguema, G., Carteret, C., Benali, O., Abdelmoula, M., Genin, J.M., Jorand, F., 2002. Iron(II,III) hydroxycarbonate green rust formation and stabilization from lepidocrocite bioreduction. Environmental Science \& Technology 36, 16-20.

Ona-Nguema, G., Carteret, C., Benali, O., Abdelmoula, M., Genin, J.M., Jorand, F., 2004. Competitive formation of hydroxycarbonate green rust 1 versus hydroxysulphate green rust 2 in Shewanella putrefaciens cultures. Geomicrobiology Journal 21, 79-90.

Ona-Nguema, G., Morin, G., Wang, Y., Menguy, N., Juillot, F., Olivi, L., Aquilanti, G., Abdelmoula, M., Ruby, C., Bargar, J.R., Guyot, F., Calas, G., Brown, Jr G.E., 2009. Arsenite sequestration at the surface of nano $\mathrm{Fe}(\mathrm{OH})_{2}$ ferrous-carbonate hydroxide and green rust after bioreduction of arsenic-sorbed lepidocrocite by Shewanella putrefaciens. Geochimica et Cosmochimica Acta 73, 1359-1381.

Oremland, R.S., Stolz, J.F., 2003. The ecology of arsenic. Science 300, 939-944. 
Parsons, C.T., Couture, R.-M., Omoregie, E.O., Bardelli, F., Greneche, J.-M., Roman-Boss, G., Charlet, L., 2013. The impact of oscillating redox conditions: arsenic immobilisation in contaminated calcareous floodplain soils. Environmental Pollution 178, 254-263.

Pedersen, H.D., Postma, D., Jakobsen, R., 2006. Release of arsenic associated with the reduction and transformation of iron oxides. Geochimica et Cosmochimica Acta 70, 41164129.

Pérez-Jiménez, J.R., DeFraia, C., Young, L.Y., 2005. Arsenate respiratory reductase gene (arrA) for Desulfosporosinus sp. strain Y5. Biochemical and Biophysical Research Communications 338, 825-829.

Pester, M., Bittner N., Deevong P., Wagner M., Loy A., 2010. A "rare biosphere" microorganism contributes to sulfate reduction in a peatland. ISME J 4, 1591-1602.

Pester, M., Knorr K.H., Friedrich M.W., Wagner M., Loy, A., 2012. Sulfate-reducing microorganisms in wetlands-fameless actors in carbon cycling and climate change. Frontiers in Microbiology 3, 72.

Ponnamperuma, F.N., 1972. The chemistry of submerged soils. Advances in Agronomy 24, 29-96.

Postma, D., Jakobsen, R., 1996. Redox zonation: equilibrium constraints on the $\mathrm{Fe}(\mathrm{III}) / \mathrm{SO}_{4^{-}}$ reduction interface. Geochimica Cosmochimica Acta 60, 3169-3175.

Quantin, C., Becquer, T., Rouiller, J.H., Berthelin, J., 2001. Oxide weathering and trace metal release by bacterial reduction in a New Caledonia Ferralsol. Biogeochemistry 53, 323-340.

Quantin, C., Becquer, T., Rouiller, J.H., Berthelin, J., 2002. Redistribution of Metals in a New Caledonia Ferralsol After Microbial Weathering. Soil Science Society of America Journal 66, 1797-1804.

Randall, S.R., Sherman, D.M., Ragnarsdottir, K.V., 2001. Sorption of As(V) on green rust $\left(\mathrm{Fe}_{4}(\mathrm{II}) \mathrm{Fe}_{2}(\mathrm{III})(\mathrm{OH})_{12} \mathrm{SO}_{4} \cdot 3 \mathrm{H}_{2} \mathrm{O}\right)$ and lepidocrocite $(\gamma-\mathrm{FeOOH})$ : surface complexes from EXAFS spectroscopy. Geochimica et Cosmochimica Acta 65, 1015-1023.

Raven, K.P., Jain, A., Loeppert, R.H., 1998. Arsenite and arsenate adsorption on ferrihydrite: Kinetics, equilibrium, and adsorption envelopes. Environmental Science \& Technology 32, 344-349.

Rhine, E.D., Garcia-Dominguez, E., Phelps, C.D., Young, L.Y., 2005. Environmental microbes can speciate and cycle arsenic. Environmental Science \& Technology 39, 95699573.

Rickard, D., Luther, G.W., 2007. Chemistry of iron Sulfide. Chemical Reviews 107, $514 \square 562$.

Roden, E.E., Zachara, J.M., 1996. Microbial reduction of crystalline iron(III) oxides: Influence of oxide surface area and potential for cell growth. Environmental Science \& Technology 30, 1618-1628.

Roden, E.E., 2003. Fe(III) oxide reactivity toward biological versus chemical reduction. Environmental Science \& Technology 37, 1319-1324. 
Roden, E.E., 2004. Analysis of long-term bacterial vs. chemical Fe(III) oxide reduction kinetics. Geochim Cosmochim Acta 68, 3205-3216.

Roden, E.E., 2006. Geochemical and microbiological controls on dissimilatory iron reduction. Comptes Rendus Geosciences 338, 456-467.

Rosen, B.P., 1999. Families of arsenic transporters. Trends in Microbiology 7, 207-212.

Root, R.A, Dixit, S., Campbell, K.M., Jew, A.D., Hering, J.G., O'Day, P.A., 2007. Arsenic sequestration by sorption processes in high-iron sediments. Geochimica et Cosmochimica Acta 71, 5782-5803.

Saitou, N., Nei, M., 1987. The neighbor-joining method: A new method for reconstructing phylogenetic trees. Molecular Biology and Evolution 4, 406-425.

Schloss, P.D., Westcott, S.L., Ryabin, T., Hall, J.R., Hartmann, M., Hollister, E.B., Lesniewski, R.A., Oakley, B.B., Parks, D.H., Robinson, C.J., Sahl, J.W., Stres, B., Thallinger, G.G., Van Horn, D.J., Weber, C.F., 2009. Introducing mothur: open-source, platform-independent, community-supported software for describing and comparing microbial communities. Applied and Environmental Microbiology 75, 7537-7541.

Schwertmann, U., Taylor, R.M., 1989. Iron oxides. In: J.B. Dixon, S.B. Weed (Editors), Minerals in soil environments. ASA and SSSA, Madison, WI, pp. 379-438.

Schwertmann, U., Cornell, R.M., 2000. Iron oxides in the laboratory: Preparation and Characterization. Second, Completely Revised and Extended Edition, Wiley-VCH, p188.

Smedley, P.L., Kinniburgh, D.G., 2002. A review of the source, behaviour and distribution of arsenic in natural waters. Applied Geochemistry 17, 517-568.

Slobodkin, A., 2005. Thermophilic microbial metal reduction. Microbiology 74, 501-514.

Tamura, K., Dudley, J., Nei, M., Kumar, S., 2007. MEGA4: Molecular Evolutionary Genetic Analysis (MEGA) software version 4.0. Molecular Biology and Evolution 24, 1596-1599.

Tipping, E., 1998. Humic ion-binding model VI: an improved description of the interactions of protons and metal ions with humic substances. Aquatic Geochemistry 4, 3-48.

Torsvik, V., Øvreås, L., Thingstad, T.F., 2002. Prokaryotic diversity - Magnitude, dynamics, and controlling factors. Science 296, 1064-1066.

Tringe, S.G., von Mering, C., Kobayashi, A., Salamov, A.A., Chen, K., Chang, H.W, Podar, M., Short, J.M., Mathur, E.J., Detter, J.C., Bork, P., Hugenholtz, P., Rubin, E.M., 2005. Comparative metagenomics of microbial communities. Science 308, 554-557.

Tufano, K.J., Fendorf, S., 2008. Confounding impacts of iron reduction on arsenic retention. Environmental Science \& Technology 42, 4777-4783.

Urrutia, M.M., Roden, E.E., Fredrickson, J.K., Zachara, J.M., 1998. Microbial and geochemical controls on synthetic Fe(III) oxide reduction by Shewanella alga strain BrY. Geomicrobiology Journal 15, 269-291. 
Van Geen, A., Rose, J., Thoral, S., Garnier, J.-M., Zheng, Y., Bottero, J.-Y., 2004. Decoupling of As and Fe release to Bangladesh groundwater under reducing conditions. Part II. Evidence from sediment incubations. Geochimica et Cosmochimica Acta 68, 34753486.

Van Geen, A., Zheng, Y., Goodbred, S., Horneman, J.R.A., Aziz, Z., Cheng, Z., Stute, M., Mailloux, B., Weinman, B., Hoque, M.A., Seddique, A.A., Hossain, M.S., Chowdhury, S.H., Ahmed, K.M., 2008. Flushing history as a hydrogeological control on the regional distribution of arsenic in shallow groundwater of the Bengal basin. Environmental Science \& Technology 42, 2283-2288.

Voegelin, A., Scheinost, A.C., Buhlmann, K., Barmettler, K., Kretzschmar, R., 2002. Slow formation and dissolution of $\mathrm{Zn}$ precipitates in soil - A combined column-transport and XAFS study. Environmental Science \& Technology 36, 3749-3754.

Wahid, P.A., Kamalam, N.V., 1993. Reductive dissolution of crystalline and amorphous Fe(III) oxides by microorganisms in submerged soil. Biology and Fertility of Soils 15, 144-148.

Wang, Y., Morin, G., Ona-Nguema, G., Menguy, N., Juillot, F., Aubry, E., Guyot, F., Calas, G., Brown, Jr. G.E., 2008. Arsenite sorption at the magnetite-water interface during aqueous precipitation of magnetite. EXAFS evidence of a new surface complex. Geochimica et Cosmochimica Acta 72, 2573-2586.

Wrighton, K.C., Thrash, J.C., Melnyk, R.A., Bigi, J.P., Byrne-Bailey, K.G., Remis, J.P., Schichnes, D., Auer, M., Chang, C.J., Coates, J.D., 2011. Evidence for direct electron transfer by a gram-positive bacterium isolated from a microbial fuel cell. Applied Environmental Microbiology 77, 7633-7639.

Yéghicheyan, D., Carignan, J., Valladon, M., Le Coz, M.B., Cornec, F.L., Castrec-Rouelle, M.,Robert, M., Aquilina, L., Aubry, E., Churlaud, C., Dia, A., Deberdt, S., Dupré, B.,Freydier, R., Gruau, G., Hénin, O., de Kersabiec, A.-M., Macé, J., Marin, L., Morin, N.,Petitjean, P., Serrat, E., 2001. A compilation of silicon and thirty one trace elements measured in the natural river water reference material SLRS-4 (NRC-CNRC). Geostand. Newslett. 25, 465-474.

Zachara, J.M., Fredrickson, J.K., Smith, S.C., Gassman, P.L., 2001. Solubilization of Fe(III) oxide-bound trace metals by a dissimilatory Fe(III) reducing bacterium. Geochimica et Cosmochimica Acta 65, 75-93.

Zachara, J.M., Kukkadapu, R.K., Fredrickson, J.K., Gorby, Y.A., Smith, S.C., 2002. Biomineralization of poorly crystalline $\mathrm{Fe}(\mathrm{III})$ oxides by dissimilatory metal reducing bacteria (DMRB). Geomicrobiology Journal 19, 179-207.

Zavarzina, D., Sokolova, T., Tourova, T., Chernyh, N., Kostrikina, N., Bonch-Osmolovskaya, E., 2007. Thermincola ferriacetica; a new anaerobic, thermophilic, facultatively chemolithoautotrophic bacterium capable of dissimilatory Fe(III) reduction. Extremophiles $11,1-7$.

Zegeye, A., Ona-Nguema, G., Carteret, C., Huguet, L., Abdelmoula, M., Jorand, F., 2005. Formation of hydroxysulphate green rust 2 as a single Iron(II, III) mineral in microbial culture. Geomicrobiology Journal 22, 389-399. 
Zuckerkandl, E., Pauling, L., 1965. Evolutionary divergence and convergence in proteins. in: Bryson, V., Vogel, H.J. (Eds.). Evolving Genes and Proteins, Academic Press, New York, pp. 97-166.

\section{FIGURE CAPTIONS}

Figure 1. a) $\mathrm{pH}$ and redox potential (Eh) of the soil solution are plotted against time (expressed in weeks) throughout the experiment. b) Nitrate, $\mathrm{SO}_{4}{ }^{2-}$ and $\mathrm{CH}_{3} \mathrm{COO}^{-}$ concentrations $\left(\mathrm{mg} \mathrm{L}^{-1}\right)$, as well as Dissolved Organic Carbon (DOC) and Dissolved Inorganic Carbon (DIC) concentrations $\left(\mathrm{mg} \mathrm{L}^{-1}\right)$ are plotted against time (in weeks). c) Total $\mathrm{Fe}$ and $\mathrm{Fe}(\mathrm{II})$ concentrations $\left(\mathrm{mg} \mathrm{L}^{-1}\right)$ are plotted against time (in weeks). d) Total As (Astot), $\mathrm{As}(\mathrm{III})$ and $\mathrm{As}(\mathrm{V})$ concentrations $\left(\mu \mathrm{g} \mathrm{L}^{-1}\right)$ are plotted against time (in weeks).

Figure 2. Saturation indexes of siderite, green rusts: $\left[\mathrm{FeII}{ }_{3} \mathrm{FeIII}(\mathrm{OH}) \mathrm{Cl}\right]$ and $\left[\mathrm{FeII}_{4} \mathrm{Fe} \mathrm{III}_{2}(\mathrm{OH})_{12} \mathrm{CO}_{3}\right]$, hydroxy green rusts: $\left[\mathrm{FeIII}{ }_{2} \mathrm{FeII}(\mathrm{OH})_{8}\right]$ and $\left[\mathrm{FeIIFeIII}(\mathrm{OH})_{5}\right]$ and $\mathrm{Fe}$ $(\mathrm{OH})_{2}$ versus time for the incubation experiment as modelled with PHREEQC/Model VI (Marsac et al., 2011). The proportion of Fe(II) complexed to organic matter is also reported throughout the experiment.

Figure 3. Scanning Electron Microscopy (SEM) pictures: a) pristine As(V)-doped lepidocrocite, b) bacteria colonization on lepidocrocite after one week of incubation as pointed out by the white arrow. c) The black arrow shows an encrusted bacterium within a gap (white arrow) after four weeks of incubation. d) Thick biofilm (white arrow) and 3-D alteration (black arrows) can be observed after eight weeks of incubation. Bacteria can be seen in the gap below the biofilm. e) Large bacterial-mediated 3-D alteration as evidenced by the numerous black holes seen in the picture.

Figure 4. Phylogenetic analysis of the deduced amino acid sequences encoded by ars $B$ gene sequences from an As(V)-doped lepidocrocite wetland soil. Slides covered with As(V)doped lepidocrocite were incubated during 3 and 8 weeks in a column containing a wetland soil (Mercy wetland, France). The tree was inferred using the Neighbor-Joining method. The percentages of replicate trees in which the associated taxa clustered together in the bootstrap test (1000 replicates) are shown next to the branches. The branch length units are the same as those of the evolutionary distances used to infer the phylogenetic tree. The evolutionary distances were computed using the Poisson correction method and are in the units of the 
number of amino acid substitutions per site. BLAST best matches and percentage of similarity are indicated along one sequence for each cluster.

Figure 5. Phylogenetic analysis of the deduced amino acid sequences encoded by Acr3(1) gene sequences from an As(V)-doped lepidocrocite wetland soil. See Figure A.2 caption for further information

\section{TABLE CAPTIONS}

Table 1 Soil composition. $\mathrm{C}_{\text {org, }}$ LOI and REE refer to organic carbon, Loss On Ignition and Rare Earth Elements, respectively.

Table 2 Soil solution data through time.

Table 3 Succession of the bacteria colonizing the lepidocrocite, as represented by the phylogenetic classes and genera identified in the clone libraries. The range of percent similarity with each genus is indicated in brackets. The shading is proportional to the relative abundance of the clones. nd refers to not detected.

\section{APPENDICES - SUPPORTING INFORMATION}

Figure A.1 X-Ray Diffraction pattern of the synthesized As(V)-lepidocrocite.

Figure A.2 T-RFLP profiles showing the dynamics of the bacterial communities colonizing the lepidocrocite, from week 1 to week 8. T-RFs corresponding to strains identified in the $16 \mathrm{~S}$ gene library are indicated over each peak along the fragment length. The $\mathrm{x}$-axis indicates the length of the fragments, whereas the y-axis corresponds to the fluorescence intensity.

Figure A.3 Gibbs free energies $\left(\Delta \mathrm{G}_{\mathrm{r}}\right)$ are displayed through time. The total soil Fe content or the highest solubilized Fe(II) concentrations - symbols labelled (a) and (b), respectively were considered as the source of the Fe. The produced acetate was used as the source of the labile C. The calculations were performed considering $\mathrm{Fe}(\mathrm{III})$ and $\mathrm{As}(\mathrm{V})$ as $\gamma$-FeOOH (Lepidocrocite) or $\mathrm{Fe}(\mathrm{OH})_{3}$ and as $\mathrm{HAsO}_{4}{ }^{2-}$ or $\mathrm{H}_{2} \mathrm{AsO}_{4}{ }^{-}$, respectively.

Table A.1 Primers used to target the 16S RNA genes and other genes involved in As transformation.

Table A.2 Percent coverage of the clone libraries, calculated at 97\% similarity. 


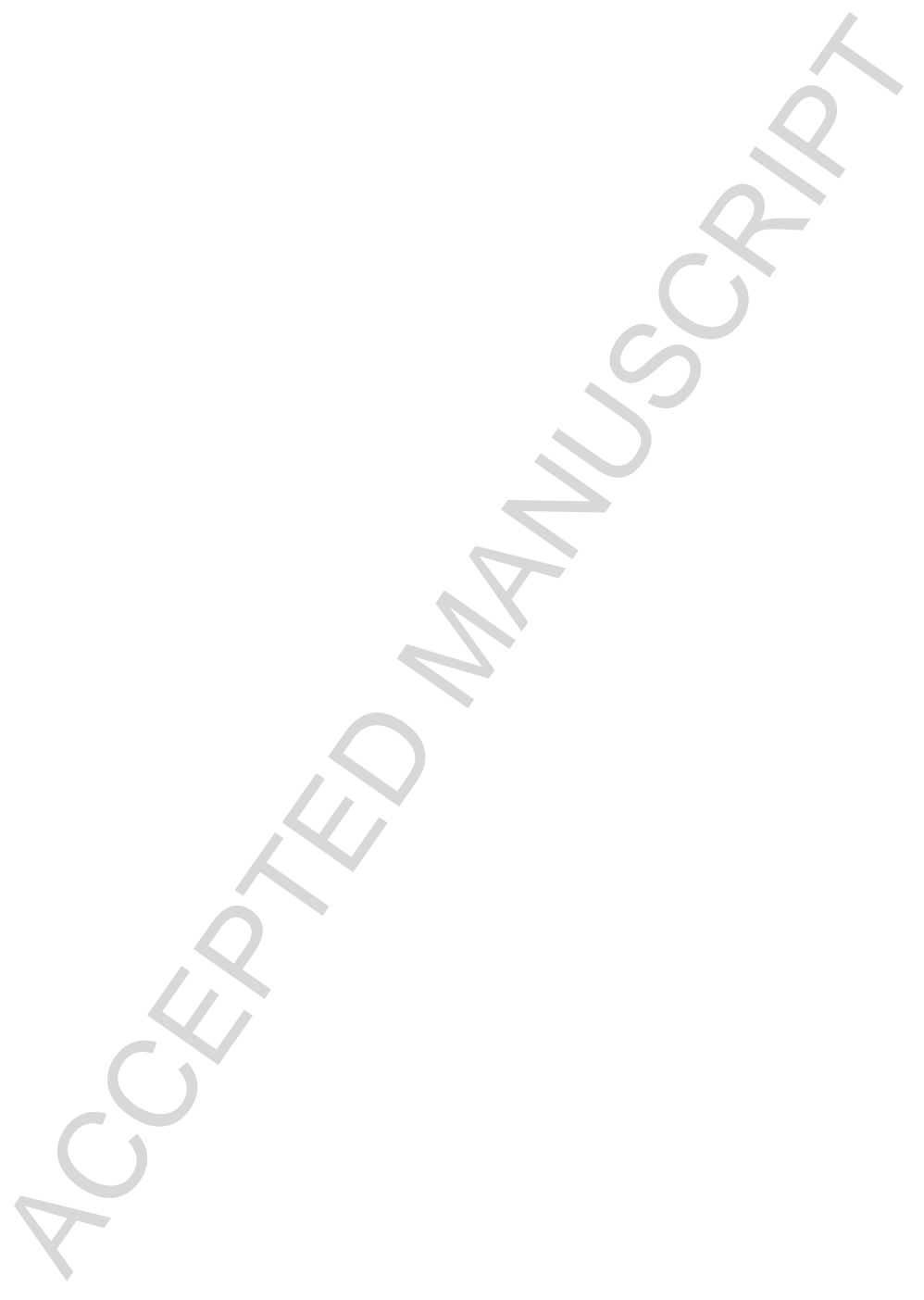




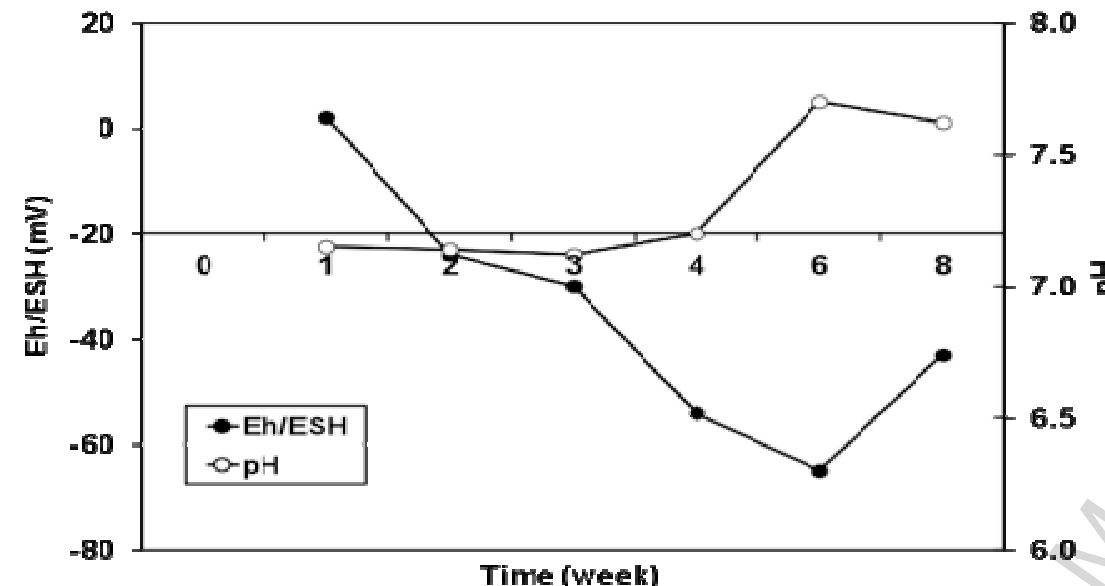

a)

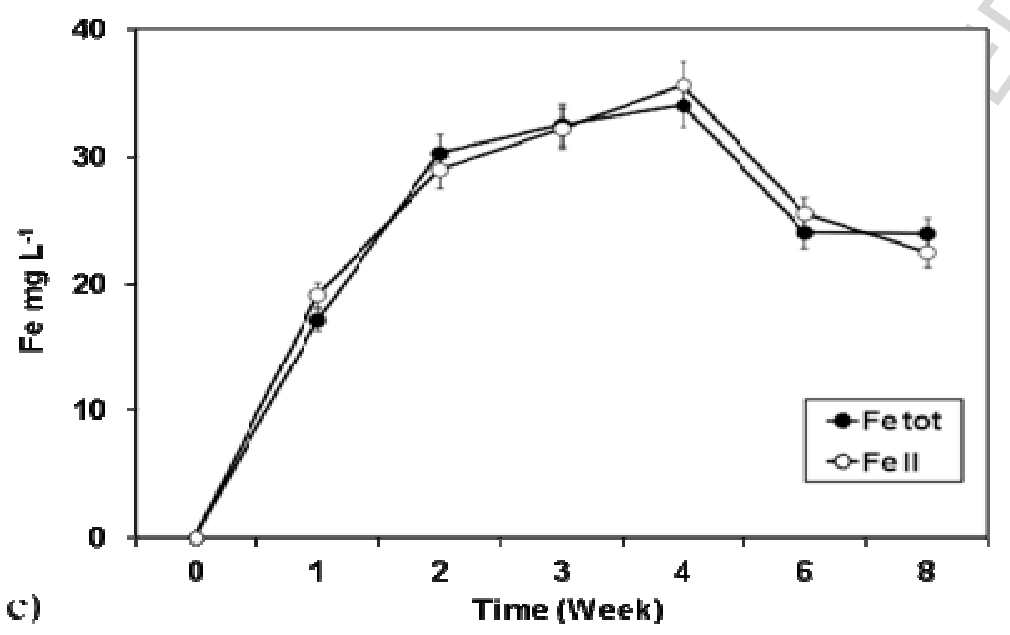

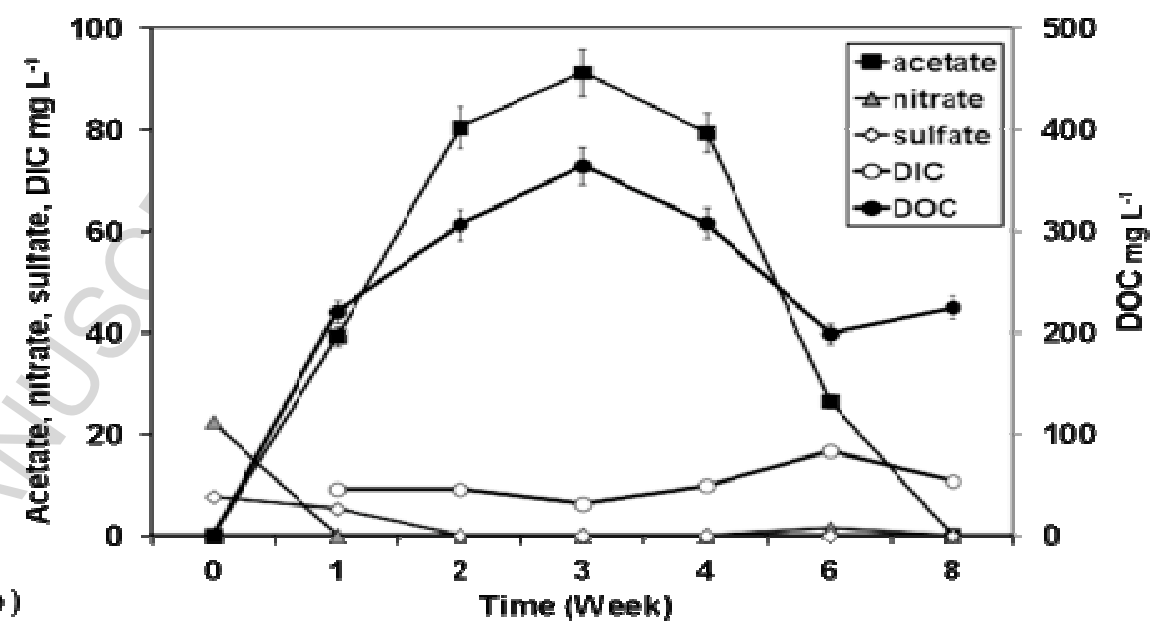

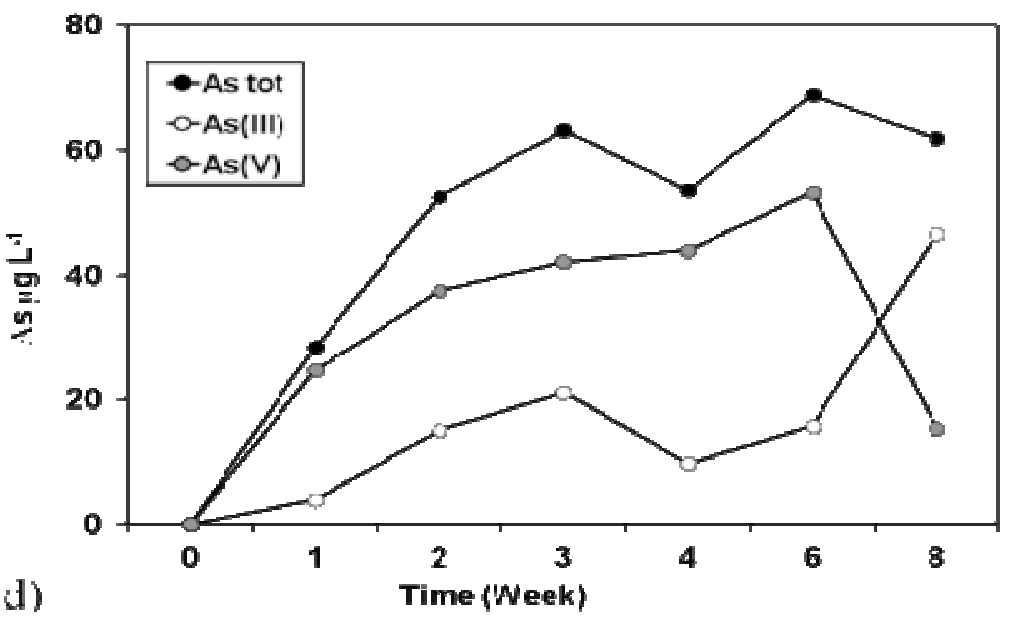




\section{Figure 1}

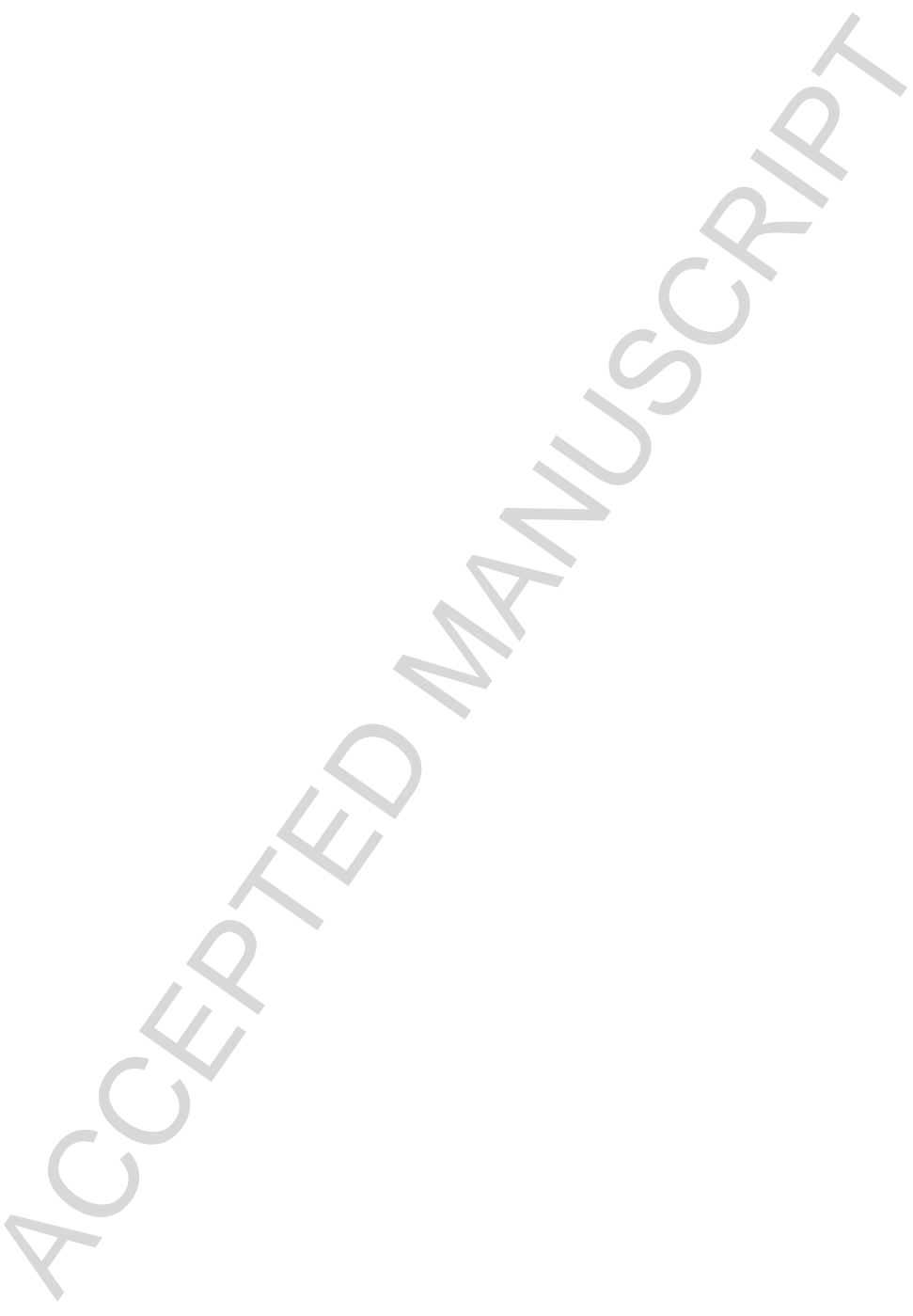




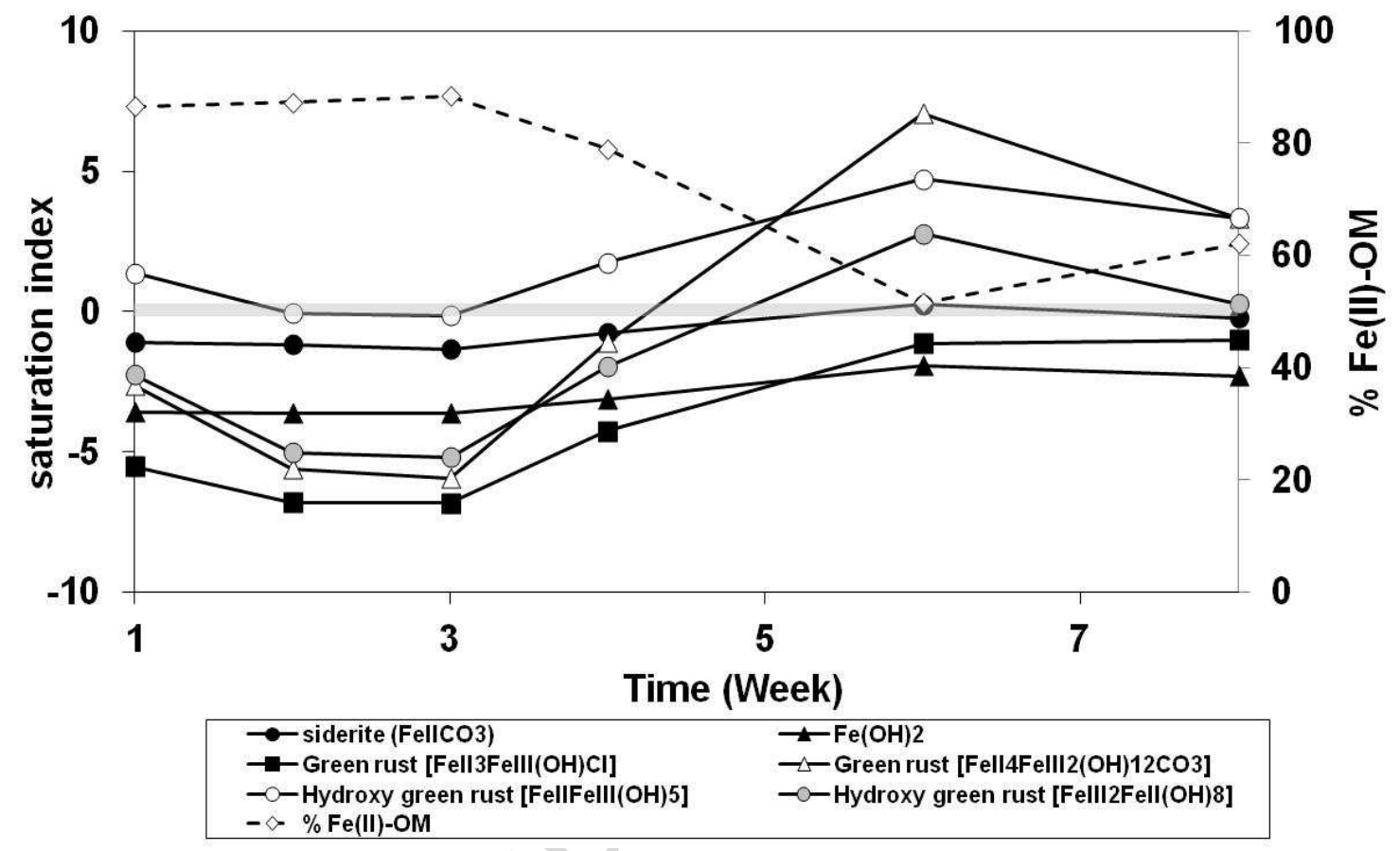

Figure 2 
a)

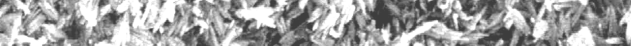

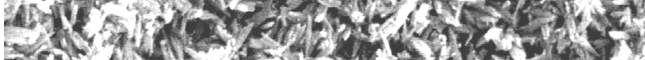
12.

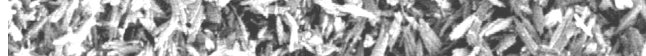
M. 1010150010

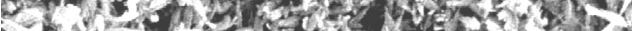

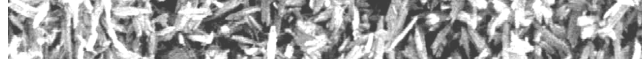
by

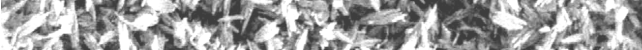

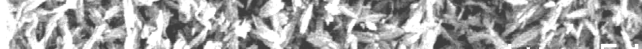

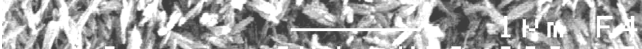

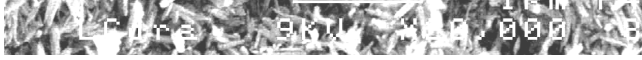

d)
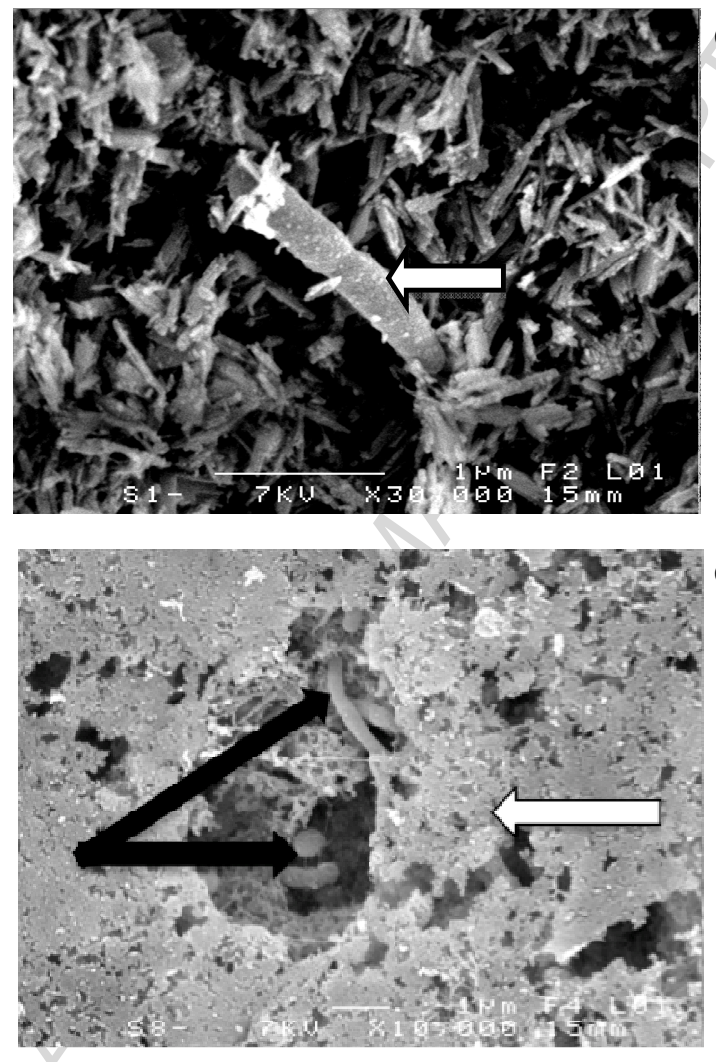

c)

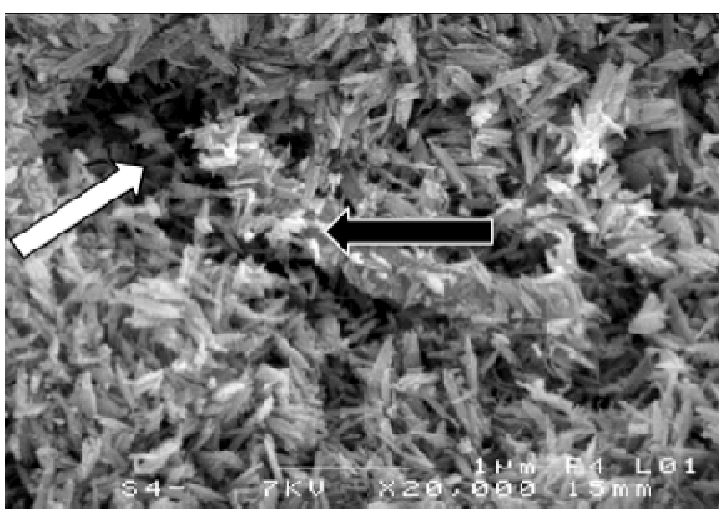

e)

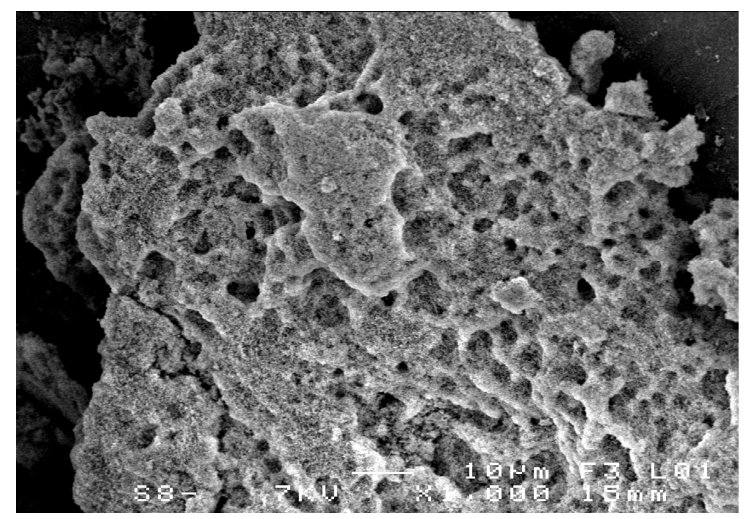

Figure 3 


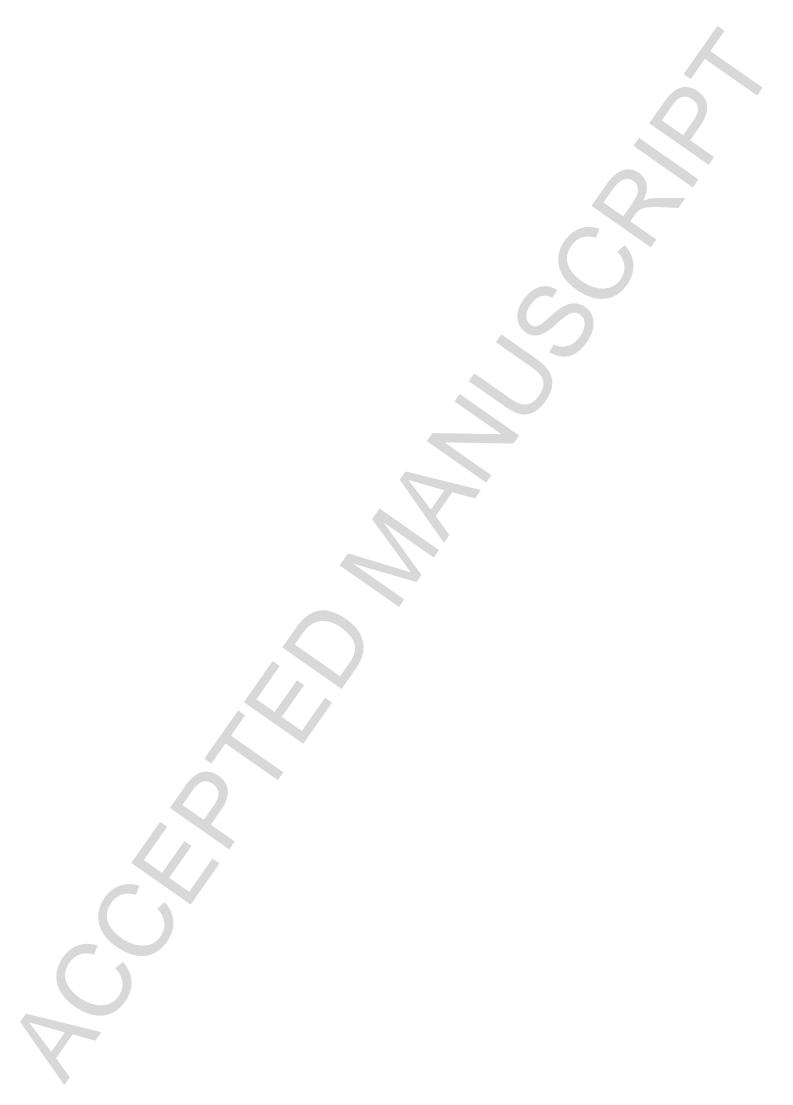




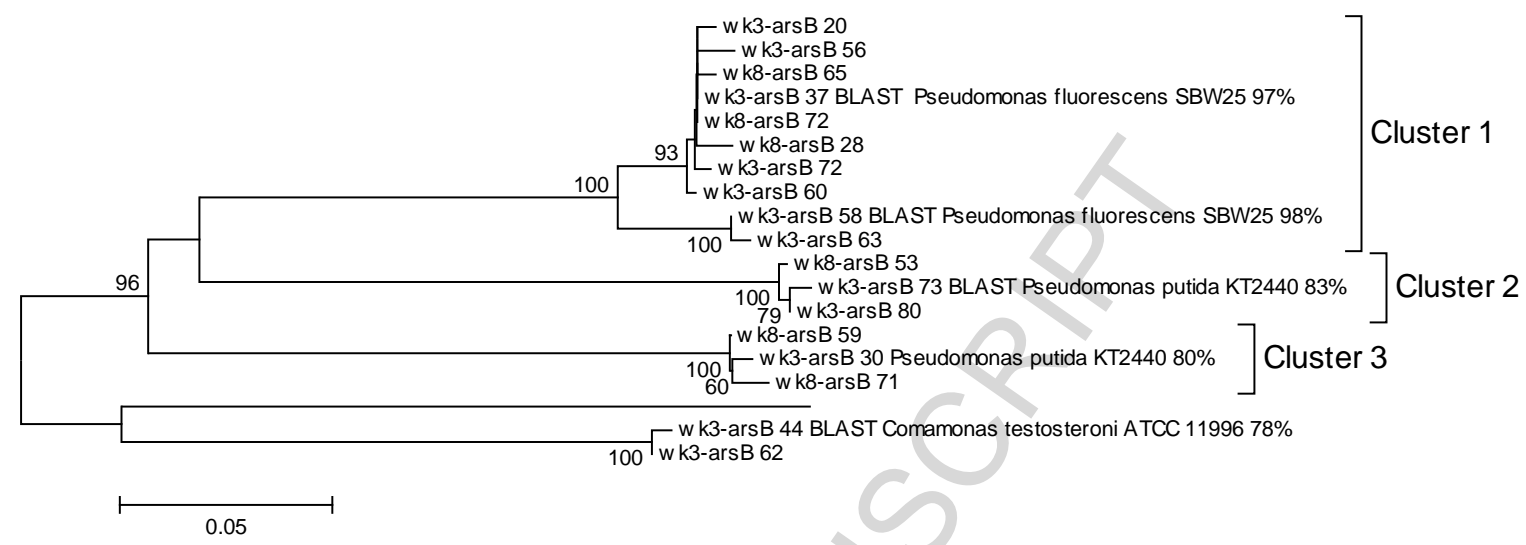

\section{Figure 4}

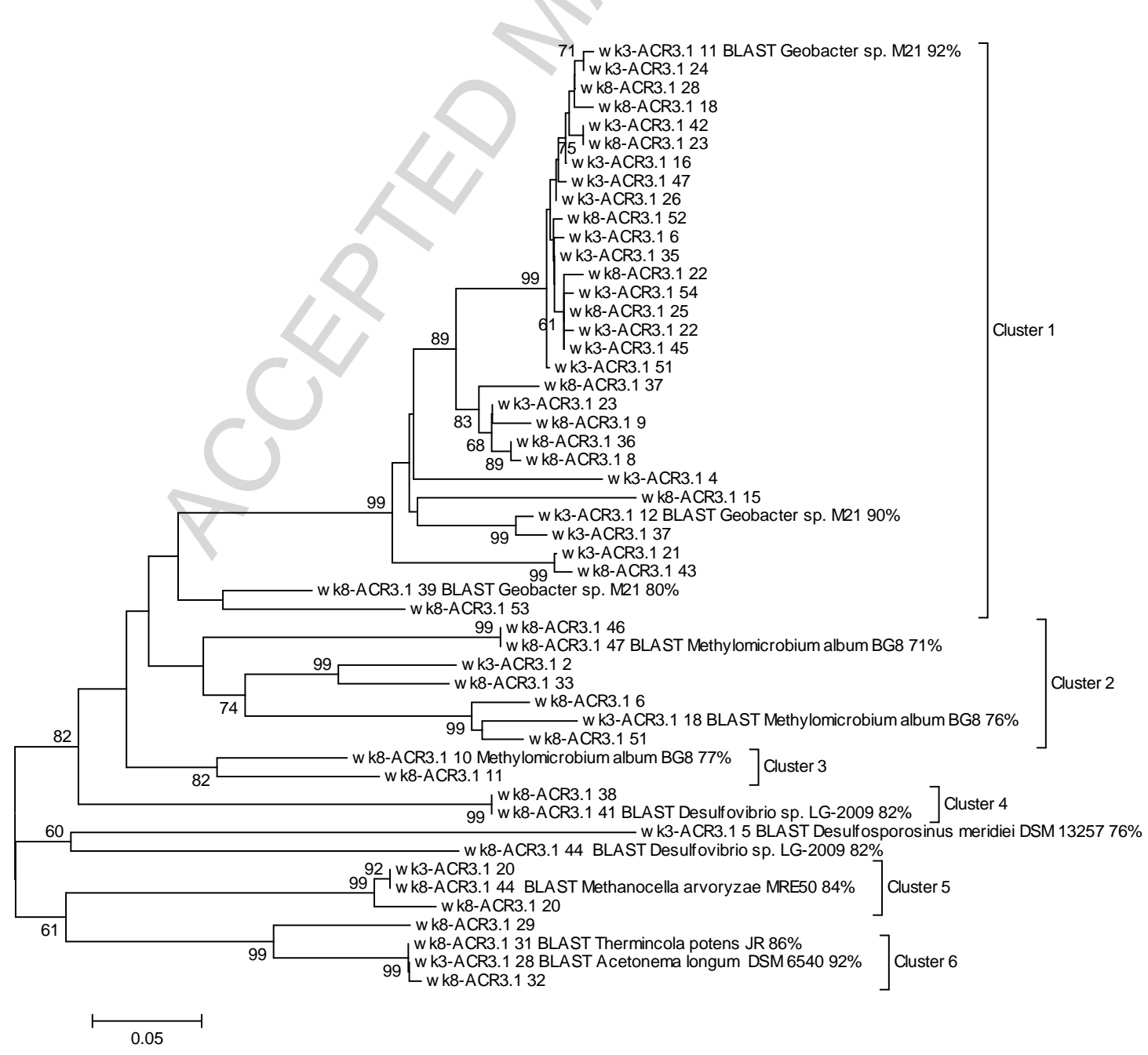


Figure 5

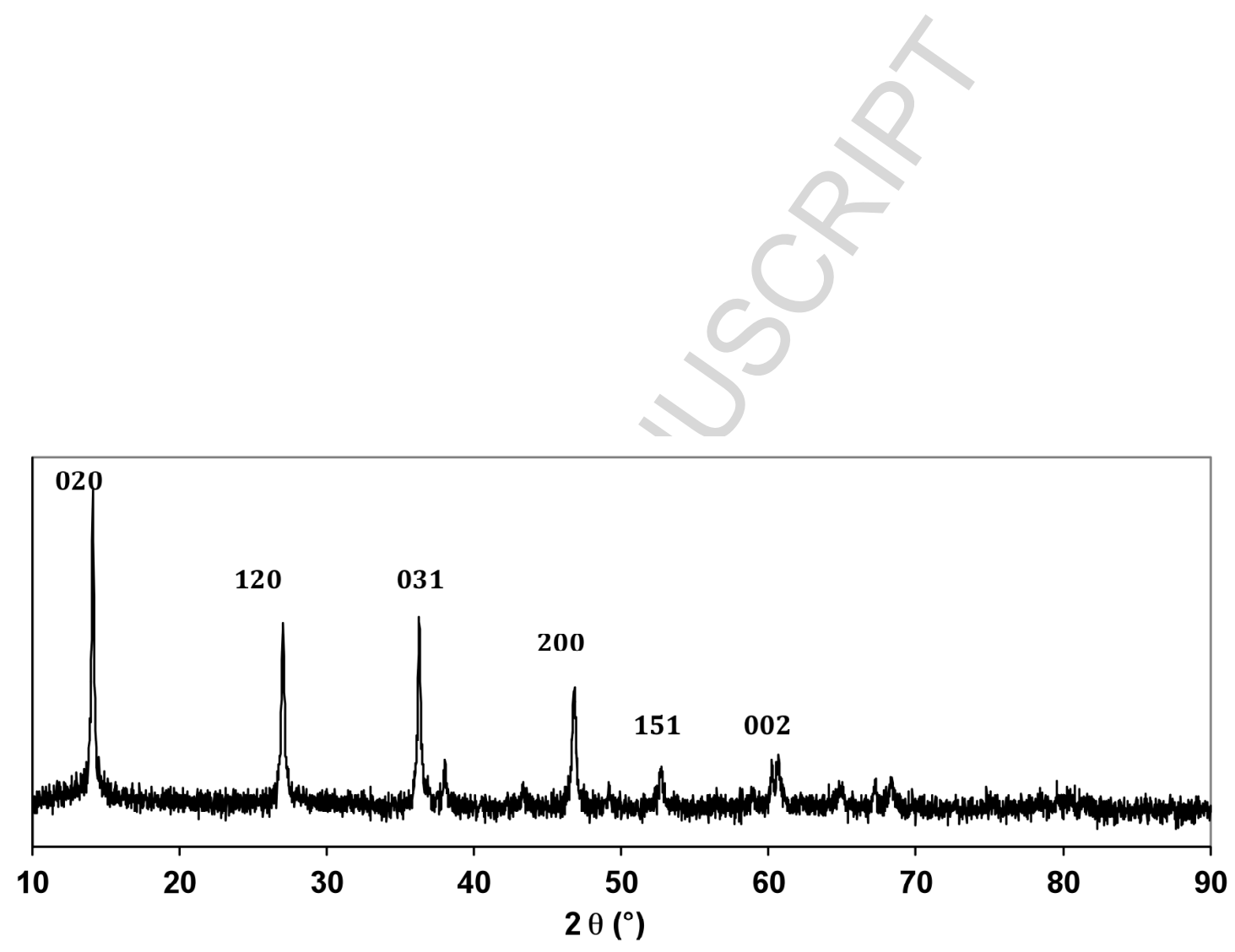

Figure A.1

(Supporting Information) 


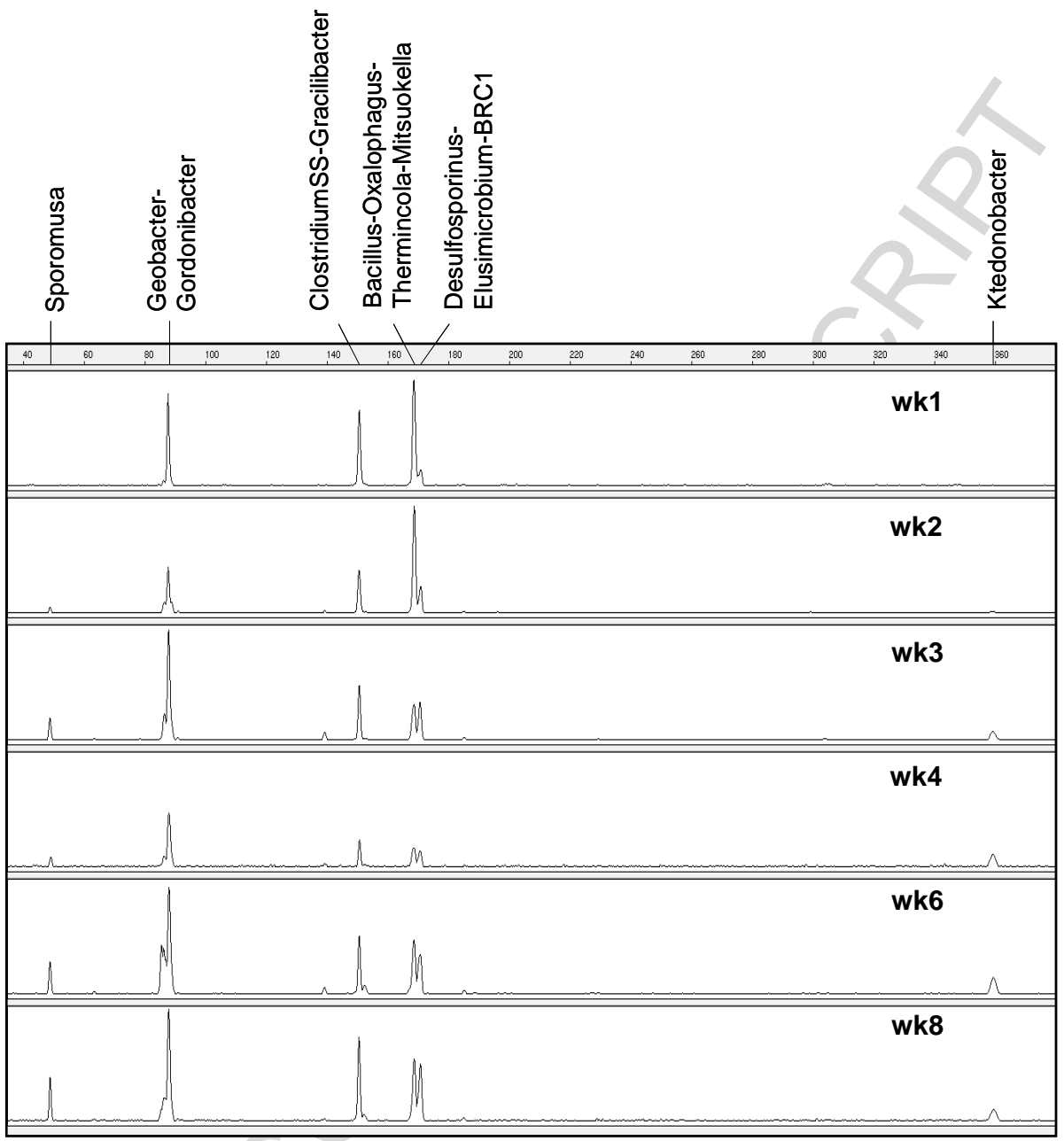

Figure A.2

(Supporting Information) 


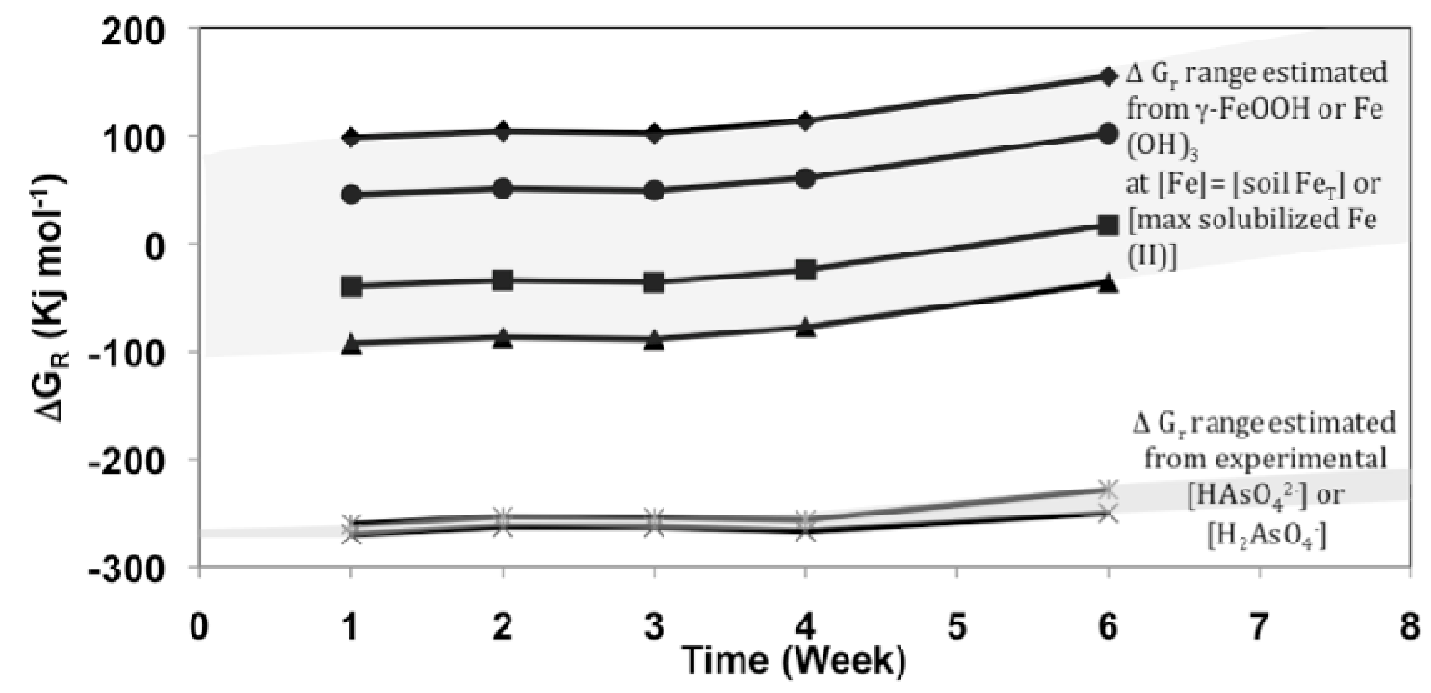

$\multimap \mathrm{FeOOH}(\mathrm{a}) \rightarrow \mathrm{Fe}(\mathrm{OH}) 3(\mathrm{a}) \rightarrow \mathrm{FeOOH}(\mathrm{b}) \rightarrow \mathrm{Fe}(\mathrm{OH}) 3(\mathrm{~b}) \rightarrow \mathrm{HAsO42-} \rightarrow \mathrm{H} 2 \mathrm{AsO}-$

\section{Figure A.3}

\section{(Supporting Information)}

\begin{tabular}{|c|c|c|c|c|c|c|c|c|c|c|c|c|}
\hline $\begin{array}{c}\text { Major } \\
\text { elements (\%) }\end{array}$ & $\mathbf{S i}$ & Al & $\mathbf{F e}$ & Mn & Mg & $\mathrm{Ca}$ & $\mathrm{Na}$ & $\mathbf{K}$ & $\mathbf{T i}$ & $\mathbf{P}$ & $\mathrm{C}_{\text {org }}$ & LOI \\
\hline & 58.4 & 5.7 & 1.4 & 0.01 & 0.40 & 0.25 & 0.18 & 1.00 & 0.36 & 0.06 & 6.64 & 22.56 \\
\hline \multirow{2}{*}{$\begin{array}{c}\text { Trace } \\
\text { elements }\left(\mu \mathrm{g} . \mathrm{g}^{-}\right. \\
\text {1) }\end{array}$} & As & Cd & Co & $\mathrm{Cr}$ & $\mathrm{Cu}$ & $\mathbf{N i}$ & $\mathbf{P b}$ & Zn & REE & & & \\
\hline & 7.64 & 0.29 & 4.79 & 74.88 & 10.51 & 21.26 & 25.13 & 40.96 & 126.7 & & & \\
\hline
\end{tabular}


Table 1

\begin{tabular}{|l|ccccccc|}
\hline Time (Weeks) & $\mathbf{0}$ & $\mathbf{1}$ & $\mathbf{2}$ & $\mathbf{3}$ & $\mathbf{4}$ & $\mathbf{6}$ & $\mathbf{8}$ \\
\hline \hline $\mathbf{p H}$ & $/$ & 7.15 & 7.14 & 7.12 & 7.2 & 7.7 & 7.62 \\
$\mathbf{E h}(\mathbf{m V})$ & $/$ & 2 & -24 & -30 & -54 & -65 & -43 \\
$\mathbf{N O}_{\mathbf{3}}^{-}\left(\mathbf{m g ~ L}^{-\mathbf{1}}\right)$ & 30.91 & $<\mathrm{q} l$ & $<\mathrm{ql}$ & $<\mathrm{ql}$ & $<\mathrm{ql}$ & $<\mathrm{ql}$ & $<\mathrm{ql}$ \\
$\mathbf{S O}_{\mathbf{4}}{ }^{{ }^{2-}}\left(\mathbf{m g ~ L}^{\mathbf{- 1}}\right)$ & 10.62 & 5.24 & $<\mathrm{ql}$ & $<\mathrm{ql}$ & $<\mathrm{ql}$ & $<\mathrm{ql}$ & $<\mathrm{ql}$ \\
\end{tabular}

Table 2

\begin{tabular}{|c|c|c|c|c|c|c|c|}
\hline $\mathrm{CH}_{3} \mathrm{COO}^{-}\left(\mathrm{mg} \mathrm{L}^{-1}\right)$ & 0 & 9.27 & 80.41 & 91.20 & 79.39 & 26.52 & 4.97 \\
\hline DOC $\left(\mathrm{mg} \mathrm{L}^{-1}\right)$ & & .41 & 306.35 & 364.29 & 307.64 & 198.61 & 224.96 \\
\hline DIC (1 & 0 & 12.11 & 9.05 & 6.19 & 9.78 & 16.69 & 10.66 \\
\hline $\mathrm{Fe}(\mathrm{II})\left(\mathrm{mg} \mathrm{L}^{-1}\right)$ & 0 & 19.18 & 28.98 & 32.21 & 35.63 & 25.57 & 22.52 \\
\hline$A s_{\text {tot }}\left(\mu g \mathbf{L}^{-1}\right)$ & 0 & 28.52 & 52.59 & 63.23 & 53.69 & 68.88 & 61.89 \\
\hline $\operatorname{As}(\mathrm{III})\left(\mu \mathrm{g} \mathbf{L}^{-1}\right)$ & 0 & 3.87 & 14.97 & 21.01 & 9.69 & 15.59 & 46.61 \\
\hline $\operatorname{As}(\mathbf{V})\left(\mu \mathrm{g} \mathbf{L}^{-1}\right)$ & 0 & 24.65 & 37.62 & 42.22 & 44 & 53.29 & 15.28 \\
\hline $\operatorname{As}(\mathrm{III}) / \mathbf{A s}(\mathbf{V})$ & 0 & 0.16 & 0.40 & 0.50 & 0.22 & 0.29 & 3.05 \\
\hline
\end{tabular}




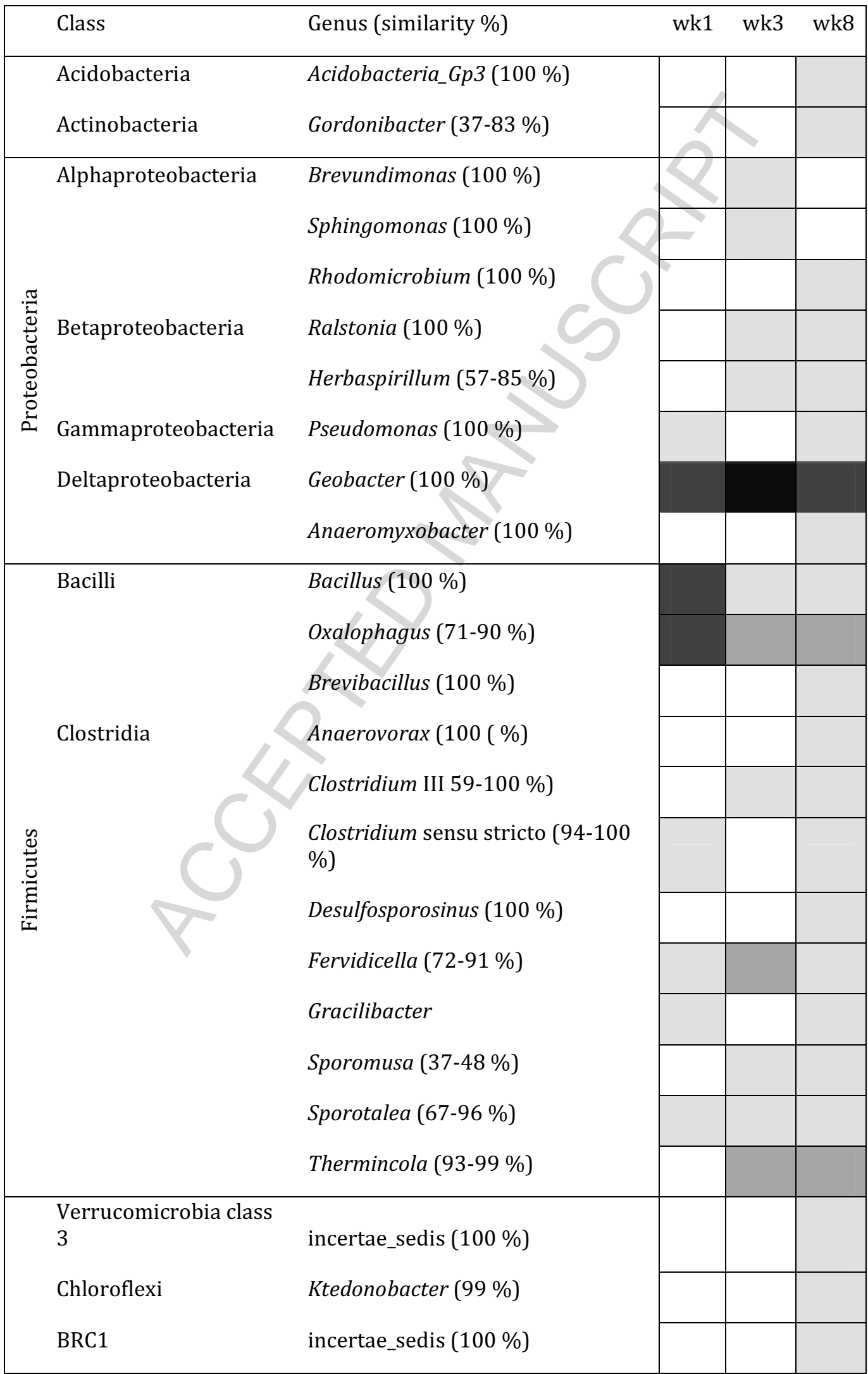


Elusimicrobia

Non affiliated

Table 3

Elusimicrobium (71- $92 \%)$ 